\title{
CAN THE MARKET FIX A WRONG ADMINISTRATIVE DECISION? MASSIVE DELISTING ON THE PRAGUE STOCK EXCHANGE
}

\section{Zuzana Fungáčová}
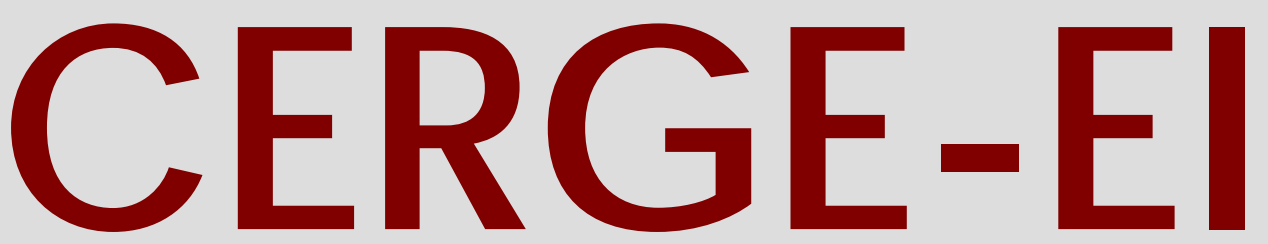

Charles University CenterforEconomic Research and Graduate Education Academy of Sciences of the Czech Republic Ec onomic s Institute 


\section{Working Paper Series 335 (ISSN 1211-3298)}

\section{Can the Market Fix a Wrong Administrative Decision? Massive Delisting on the Prague Stock Exchange}

Zuzana Fungáčová

CERGE-EI

Prague, August 2007 
ISBN 978-80-7343-134-1 (Univerzita Karlova. Centrum pro ekonomický výzkum a doktorské studium)

ISBN 978-80-7344-123-4 (Národohospodářský ústav AV ČR, v.v.i.) 


\title{
Can the Market Fix a Wrong Administrative Decision? Massive Delisting on the Prague Stock Exchange
}

\author{
Zuzana Fungáčová*
}

CERGE-EI ${ }^{\dagger}$

\begin{abstract}
This research contributes to the investigation of the emerging stock markets in transition economies, namely in the Czech Republic. We estimate the impact of the various determinants of shares delisting e.g. exclusion from public trading on the Prague Stock Exchange (PSE) during the period 1993 - 2004. Unlike its counterparts in Poland or Hungary, exceptionally large amounts of shares were delisted from the PSE. Using the data on listed and delisted companies we show that the pre-privatization and privatization characteristics of the companies were decisive for delisting. This further indicates that it would have been possible to prevent massive delisting if these factors had been taken into account when deciding which companies to place on the stock exchange for public trading. Moreover, therefore companies that were not suitable for public trading were also not suitable for voucher privatization.
\end{abstract}

\begin{abstract}
Abstrakt
Výskum sa zaoberá rozvíjajúcimi sa akciovými trhmi v tranzitívnych ekonomikách, konkrétne v Českej republike. Odhadujeme vplyv faktorov, ktoré zohrali rozhodujúcu úlohu pri delistingu t.j. vylúčení akcií z verejného obchodovania na Burze cenných papierov v Prahe v období od roku 1993 do 2004. Na rozdiel od Pol'ska a Mad'arska, bolo z pražskej burzy delistované mimoriadne vel'ké množstvo akcií. Na základe dát týkajúcich sa listovaných a delistovaných spoločností ukazujeme, že delisting môže byt' z vel'kej časti vysvetlený faktormi, ktoré boli známe už pred privatizáciou alebo počas nej. Z toho d'alej vyplýva, že ak by boli uvedené faktory zohl'adnené pri rozhodovaní o verejnom obchodovaní po privatizácii, bolo by možné predíst' masívnemu delistingu. Spoločnosti, ktoré neboli vhodné pre verejné obchodovanie neboli rovnako vhodné ani pre privatizáciu kupónovou metódou.
\end{abstract}

Keywords: mass privatization, stock market, delisting, transition economy JEL classifications: G15, G28, P34

\footnotetext{
* For valuable comments and suggestions I am grateful to Tom Berglund, Randall Filer, Jan Hanousek, Jan Kmenta, Iikka Korhonen, Andreas Ortmann and Jan Švejnar, participants of the BOFIT summer workshop in Helsinki (June 2006) and the Czech Economic Society Conference in Prague (November 2006). I would also like to thank Lawrence Smith for editing the paper. While working on this paper, I have benefited from GACR Grant No. 402/05/1014.

${ }^{\dagger}$ CERGE-EI is a joint workplace of the Center for Economic Research and Graduate Education, Charles University, and the Economics Institute of Academy of Sciences of the Czech Republic.

Address: CERGE-EI, P.O. Box 882, Politických vězňů 7, Prague 1, 111 21, Czech Republic

E-mail:zuzana.fungacova@cerge-ei.cz.
} 


\section{Introduction}

Even though financial markets in transition economies remain still underdeveloped, stock markets in these countries are becoming an important complement to banks (EBRD Transition Report 2006). These markets emerged in the course of transition to facilitate trading the shares of privatized companies. First of all, they are necessary in terms of performing the standard roles of a financial market (Levine, 2005):

- serve as a source of capital

- provide information about possible investment and improve resource allocation

- monitor investments and exert corporate governance

- risk diversification

- mobilize savings

Development of emerging stock markets has differed across transition countries. Some of the countries have followed a standard, so called "top-down", approach to stock market development characterized by gradual growth of market capitalization and the number of securities listed. On the other hand, countries that have implemented a bottom-up approach, have started with a large number of listed shares out of which only some have survived on the market (Simoneti, 1997). Thus, despite the expectations of growth in the number of listed securities as well as the amounts of trade, some stock markets in transition economies have, after the initial boom, experienced massive delisting, i.e. a large proportion of the listed share issues was excluded from public trading within a relatively short period of time. This massive delisting together with virtually no new listings highlighted the problems in fulfilling the main functions of the stock market ${ }^{1}$, which based on our conjecture, may have their roots in the way these markets were established

The phenomenon of delisting is to a certain extent a common occurrence in developed economies as well ${ }^{2}$. Nonetheless, the number of delisted share issues is insignificant compared to the size of the market. According to the New York Stock

\footnotetext{
${ }^{1}$ For example they did not fulfill their information function, see Hanousek and Filer (2000) who show that prices were disconnected with reality. Unlike Poland and Hungary, the Czech stock prices did not correspond to economic values in the period $1993-1999$.

${ }^{2}$ See for example Macey et al. (2004).
} 
Exchange (NYSE) Factbook 6\% of NYSE companies were delisted in $1997^{3}$. In the same year, $75 \%$ of companies were delisted from the Prague Stock Exchange (PSE). When considering these amounts it is, however, necessary to account for the number of new listings as well. In this respect, transition economies in general fall behind developed ones as there have been only several new listings and thus just a few companies entering the market through initial public offerings on the majority of these emerging stock markets (Köke and Schröder, 2002; Bakker and Gross, 2004).

Delisting from the transition markets can be viewed from several different perspectives. Firstly, it indicates that in some cases unsuitable companies were initially placed on the market. Here delisting undoubtedly benefited the market because these companies left the market and thus it became more transparent. On the other hand, delisting in transition economies could hurt small investors with minority holdings 4 because no exit rules were defined at the time of delisting. Furthermore, massive delisting in conjunction with practically no new listings contributed to shrinking markets, which then offered fewer investment opportunities and thus free resources had to be invested elsewhere, usually abroad.

The Czech stock market still faces the situation of having a relatively low number of liquid securities currently traded on the stock exchange ${ }^{5}$. Despite high expectations, there were no initial public offerings between June $2004^{6}$ and December 2006 and investors therefore also invest their free resources abroad. In this way they in fact indirectly finance growth of foreign economies while growth of the Czech economy

\footnotetext{
${ }^{3}$ The proportion of companies delisted from the NYSE within a year has not exceeded $10 \%$ in the period 1995 - 2002 (NYSE Factbook).

${ }^{4}$ As was the case for example in Bulgaria. For more detail see Atanasov et al. (2005).

${ }^{5}$ In fact, liquid securities are only the ones that belong to SPAD (System for Support of Share and Bond Market). Currently (March 2006) there are 11 of them (for more details see the Prague stock exchange webpage www.pse.cz). This number is low not only in comparison to other similar transition countries (e.g. Poland or Hungary, see Table A.1 in the appendix) but also in comparison to countries with a similar level of GDP per capita (e.g. in Portugal there are around 50 shares listed on the main market or South Korea where there are more than 600 listed shares). For more details see Euronext Lisbon Fact book and the statistics of the World Federation of Exchanges.

${ }^{6}$ The first successful IPO of Zentiva took place in June 2004. Zentiva is traded in SPAD, it also became part of PX-50 index and the value of its shares has almost doubled since its entry. The PSE expected several potential followers of Zentiva in 2005, however two cases of only dual listing took place: Orco and Central European Media Enterprises and it seems that Zentiva's IPO did not inspire other companies. Experts expect several new IPOs in the coming years (Ekonom 30.06.2005). Two new share issues (ECM Real Estate Investments A.G. and Pegas Nonwovens SA) however entered the stock exchange in December 2006.
} 
can be hindered ${ }^{7}$. On the other hand, there was a growing trend in the number of listed securities since the beginning of trading on the Warsaw and Budapest Stock Exchanges (see Table A.1 in the appendix). These markets are still attracting new companies, which come also from abroad. Thus, unlike the Czech market, they have already managed to fulfill the main economic function of resource allocation: they are able to provide capital to the corporate sector, especially through IPOs.

Taking into account the implemented institutional and other reforms, we suspect that differences in the development of the Czech and Slovak markets on one hand and the Polish or Hungarian stock markets on the other, have been the result of policies applied in the early stages of the transition process; most importantly privatization which, based on Korhonen et al. (2000), lays the foundation for the development of securities markets. In Poland and Hungary the primary privatization method was direct sales, while in the Czech Republic it was voucher privatization ${ }^{8}$, which even nowadays remains the subject of much discussion and controversy (Megginson, 2005). This method, as earlier research suggests (Fungáčová and Hanousek, 2006), has exhibited a negative short run impact on the emerging stock markets in transition countries. In this paper we investigate the case of the Czech Republic and consider the massive delisting that took place in 1997 to be the consequence of the way this stock market was established. We estimate the impact of different determinants of delisting that play an important role when establishing stock market in other transition countries as well. Our research examines if and how it could have been possible to prevent massive delisting and thus ensure a more standard development of emerging stock markets.

The following section provides detail description of the stock market emergence and the delisting process on the Prague Stock Exchange. Section 3 examines determinants of delisting. In sections 4 and 5 we discuss specifications of estimated models and the data used. Then, results, their interpretation and robustness follow in section 6. Section 7 concludes.

\footnotetext{
${ }^{7}$ Analysts estimate that in this way the Czech economy could lose as much as $1.5 \%$ of its growth (Ekonom 3/2005).

${ }^{8}$ Primary privatization based on the classification in the EBRD Transition Reports.
} 


\section{Privatization and stock market development in the Czech Republic}

The Prague stock exchange (PSE) started trading in the early 1990's as one of the first stock exchanges in the transition countries ${ }^{9}$. Its establishment and further functioning was closely related to voucher privatization, which was implemented in two waves. This privatization method was selected because it enabled relatively fast transformation of ownership rights. Furthermore, voucher privatization, at the time it was implemented, was considered to be rather simple, equitable and transparent and thus also socially and politically acceptable (World Bank, 2002). Any possible drawbacks were regarded as temporary, with the market expected to be strong enough to solve them and enable necessary ownership concentration (Ježek, 1997) ${ }^{10}$. Unfortunately, such expectations did not materialize. Voucher privatization failed to concentrate companies' ownership structure, minority shareholders' rights were harmed, foreign investors were not attracted and new capital necessary for companies' restructuring was not generated (Lieberman, 1997).

Moreover, voucher privatization incurred certain "hidden" costs that were not recognized at the beginning and only became obvious during or even after its implementation. These costs concern the evolution of necessary market institutions of the type that function in developed market economies ${ }^{11}$. The stock market is undoubtedly one of them. It was considered to be an important means of enabling the transfer of ownership rights, the main goal of privatization (World Development Report 1996). Thus the stock market was formally set up by the beginning of the 1990s, following the end of the first wave of voucher privatization. Under this privatization scheme shares of all privatized companies were legally required to be mandatory listed on the stock exchange ${ }^{12}$ (PSE Monthly Report, May 1997). Even though listing

\footnotetext{
${ }^{9}$ In fact the Prague Stock Exchange was reopened in the early 1990s because trading in securities existed there even before WWI.

${ }^{10}$ Ježek (1997) describes the situation after privatization when the capital market was not regulated at all as false liberalism.

11 "Czech officials deem it more important to privatise state property quickly than to settle in advance the details of a market economy," (The Economist, 1993).

12 Even though the listing was mandatory, not all the privatized companies appeared on the stock exchange. In the first wave 988 companies were privatized, however, only 955 share issues were listed. Unfortunately, even the stock exchange authorities cannot explain this phenomenon. Following the second wave there were 674 share issues listed and three issues were not listed because of their limited transferability. However, altogether 861 enterprises participated in the second privatization wave.
} 
requirements ${ }^{13}$ for companies desiring to enter the market were formally defined by 1993, privatized enterprises were not subject to them. This is not a standard approach towards stock market creation because privatization authorities not companies themselves were the ones to decide on which companies could be listed. Although the managers in the privatized companies prepared the privatization plans themselves and chose to participate in the voucher privatization program $^{14}$, later evidence from the stock exchange indicates that they did not know that this privatization method was connected to the mandatory listing of their shares ${ }^{15}$. Moreover, at the time of submission of their privatization projects to the responsible ministries, virtually no legislation concerning the stock market and its functioning was in force ${ }^{16}$.

The above description suggests that the approach to market creation adopted in the Czech Republic was a pure administrative decision that ignored the usual listing requirements and suppressed the traditional concept of stock market development. Consequently, companies that under standard conditions would prefer to be privately owned ended up being public right after the PSE was opened. The PSE started trading on April 6, 1993 and by June 22, 1993622 share issues from the first wave of voucher privatization were being traded there. Just a few weeks later, on July 13, 1993, the rest of the share issues (333) from the first wave entered the market. The number of securities grew further following the second wave of voucher privatization, when the market was "filled" with the new issues for the third time (PSE Monthly Report, May 1997). Then, 674 share issues from the second wave were introduced on March 1, 1995. Continuing the trend of a growing number of issues, the highest number of security

\footnotetext{
${ }^{13}$ Listing requirements at that time concerned the volume of an issue earmarked for public offer (min. 100 mil.CZK i.e. 3.4 mil. USD), percentage of an issue realized through public offer ( $\min .20 \%$ of the total volume of an issue), and the length of issuer's existence (min. 2 years). In fact, a lot of companies that were placed on the stock exchange after privatization did not satisfy these requirements.

${ }^{14}$ This was envisaged already before the actual privatization started: "Most companies will join, either voluntarily or on the orders of the government, a give-away scheme based on investment vouchers." (The Economist, 1991). Moreover, Kotrba (1995) suggests that authorities "recommended" mass privatization to be the most suitable method.

${ }^{15}$ PSE Monthly Report (May 1997) mentions that some issuers were surprised when they were told about their stocks being listed on the stock exchange. This is in line with a general view that many mass privatization programs were slow to recognize the natural link between privatization and development of the capital market (Lieberman, 1997).

${ }^{16}$ Companies were obliged to submit their privatization projects by October 31, 1991 for the first privatization round and by July 16, 1992 for the second round. A commercial code was enacted on November 5, 1991 and a securities law on November 20,1992. This indicates that even the policymakers were not fully aware of the connection between mass privatization and the stock exchange at the beginning.
} 
issues ever registered on the Exchange (a total of 1,792) was achieved on May 2, 1996. Market capitalization to GDP reached $31.3 \%$ in 1996, which was much higher than in any other transition economy. Similar figures at that moment were $11.66 \%$ in Hungary, $6.42 \%$ in Poland and 9.5\% in Russia (EBRD Transition report data). This number is comparable to the market capitalization figures in developed economies, however, when adjusted for the size of the public sector and investment fund holdings, the actual market capitalization in 1997 was 13.7\% (Czech Republic: Capital Market Review, 1999) $)^{17}$.

Hence, in agreement with Rozlucki (2001), voucher privatization to a large extent influenced the development of stock markets. Table A.2 in the appendix shows that voucher privatization in the Czech Republic was followed by lively trading. This was basically the result of a liberal regulatory framework and a multiplicity of trading channels (Czech Republic: Capital Market Review, 1999). Speculators were trying to take advantage of the stock market boom in early 1994. Afterwards emerging market funds from abroad entered the market. However, due to the condition prevailing on the market, these funds left it relatively soon, generally by the fall of 1996 (PSE Monthly Report, February 1997). Accordingly, as the PSE report further stresses, "the true foreign portfolio investors have not entered the market and domestic investors did not particularly care to invest in the securities either". Furthermore, the new market was rather nontransparent. This was not only due to a large number of listed securities but also because most of the transactions were conducted off the main market. In 1996 and 1997 as much as $88.5 \%$ and $91.1 \%$ of all trades at the PSE were conducted as direct and block trade (Hanousek and Podpiera, 2004). Therefore the price-setting central market on the PSE remained relatively insignificant and the prices did not carry true information. Then, after the foreign investors left and ownership structures consolidated, the main indicators of the Czech stock market functioning started to worsen (see Table A.2 in the appendix). This fact is not only reflected in the

\footnotetext{
${ }^{17}$ State holdings were deducted as they were not traded in reality. The value of investment funds holdings was also deducted because the value of their shares was added to the value of securities in which they were invested, thus they were double counted. Then, as the funds' own shares were valued at an average discount of about 40 percent relative to the portfolio value of the shares in which they were invested, this market value of investment funds shares was added. For more detail see: Czech Republic: Capital Market Review, 1999).
} 
development of prices and liquidity ${ }^{18}$ but also in a sharp decrease in the number of listed securities since an exceptionally large number of securities were delisted ${ }^{19}$ within a relatively short period of time (see Figures A.1 and A.2 in the appendix).

\subsection{Delisting process}

PSE authorities tried to improve the market's situation. To make the market more transparent and provide a better arrangement for the trading of hundreds of securities, a segmentation of the market was introduced in September 1995. The listed market was split into main and secondary markets, and the formerly unlisted securities were transformed into the free market. The securities on the main and secondary market had to fulfill certain requirements ${ }^{20}$ (certain minimal public offer, liquidity criteria, providing economic information about the company) while the free market did not impose any obligations on the securities. A large number of unlisted securities did not meet the criteria of the public market (PSE Monthly Report, May 1997). Therefore, the PSE authorities decided to reduce the number of the security issues traded and delist, i.e. exclude from public trading, issues that did not conform to the current requirements of the market. The PSE authorities also took into account the sensitive nature of such a decision, especially with respect to the significant part of the Czech population that took part in the voucher privatization. In this respect "the decision concerning delisting could not be commenced too early and 1997 seemed to be sufficiently far from the end of voucher privatization" (PSE Monthly Report, May 1997).

The process of delisting started at the end of 1996 (in December a trial round of 12 securities were delisted) when stock exchange employees even discussed this issue personally with all the affected issuers ${ }^{21}$. Until that time only an insignificant number of securities was delisted from the PSE. The reasons for delisting were mostly bankruptcy and limited transferability of the securities, that is the delisting decision was not made

\footnotetext{
${ }^{18}$ Even though standard turnover figures were relatively high, they were misleading especially due to multiple counting of transactions (which were the result of the structure of the market) and the associated dealing practices (for more detail see Czech Republic: Capital Market Review, 1999).

${ }^{19}$ Exceptionally large number when considered as a percentage of companies listed on a certain stock exchange.

${ }^{20}$ For more detailed description see the Prague Stock Exchange Factbook 1996.

${ }^{21}$ Based on the PSE Monthly Report (May 1997), some issuers were surprised when they were told that their stocks were registered on the exchange, other issuers welcomed their delisting almost enthusiastically.
} 
by the PSE authorities. In 1997, however, the PSE began to play an important role in the delisting process. The PSE (Monthly Report, May 1997) cites the following factors as crucial for the delisting decision:

- time of registration on the PSE (at least one year)

- value of trades on the central market

- value and frequency of direct and block trades

- market capitalization of the issue

- number of trading sessions with a non-zero value of trades on the central market

- ownership structure

- voluntary disclosure of the information on the issuer and the issue

- possible interests of the National Property Fund

There were four major waves of massive delisting in 1997 taking place on March 20th, April 1st, June 2nd, and October 1st. Altogether 1301 issues were excluded from trading $^{22}$. For each of these delisting waves certain criteria for delisting were set. They are presented in Table 1 below.

Table 1: Delisting criteria set by the PSE (all of them concern the period of the preceding 12 months)

\begin{tabular}{|l|c|c|c|}
\hline CRITERION & $\mathbf{1}^{\text {st }}$ and $2^{\text {nd }}$ wave & $\mathbf{3}^{\text {rd }}$ wave & $\mathbf{4}^{\text {th }}$ wave \\
\hline $\begin{array}{l}\text { Traded value in the preceding } \\
12 \text { months less than }\end{array}$ & USD 6,300 & USD 18,900 & USD 47,300 \\
\hline Market capitalization less than & USD 157,000 & USD 631,000 & \\
\hline $\begin{array}{l}\text { Number of days when security } \\
\text { was traded on the central market }\end{array}$ & less than 5 & less than 80 & less than 200 \\
\hline Displaced issues & 100 and 391 & 509 & 301 \\
\hline
\end{tabular}

Source: Prague Stock Exchange, author's calculations (based on the yearly average exchange rate reported by the Czech National Bank)

Figures in this table show that the delisted companies were very small ones that would normally not be placed on a stock exchange under standard listing conditions. They were a fraction of the size of companies that were entering other transition markets at that time (e.g. an IPO that took place on the Budapest Stock Exchange in 1997 had the

\footnotetext{
${ }^{22}$ Delisted share issues were afterwards listed on the RM-system (OTC market). Most of the delisted issues were delisted from RM-system as well, the majority of them later than one year after delisting from PSE. Nowadays, only 3\% of the issues delisted from PSE in 1997 are still traded on the RM-system.
} 
value of USD 4.477 mil.). Moreover, they did not even fulfill the official listing requirements at the PSE valid in $1997^{23}$.

A majority of listed companies were delisted in 1997. In the first wave 100 free market issues were delisted, in the second 391 issues, the third one concerned 509 share issues and the last one included 301 issues. In the first three waves for each delisted security a combination of two of the below mentioned three requirements for the period of the preceding twelve months had to be met; value and capitalization or value and the number of trading sessions ${ }^{24}$. For the fourth wave of delisting both the condition concerning minimal traded value as well as the number of days when an issue was traded on the central market had to be fulfilled. The period under consideration was again the preceding twelve months.

Afterwards, in 1998 only an insignificant number of securities was delisted, most of them because of the issuer's decision. In 1999, 75 issues were excluded from the free market on September 20th. They were already excluded from the pricing central market on February 15, 1999 due to low liquidity. This decision was meant to further contribute to increasing the transparency of the market. The amended Security Act, which entered into force on May 1, tightened the conditions for admitting and keeping securities in public markets ${ }^{25}$ and thus contributed to yet further delisting. However, the number of additional companies was low. Together there were 34 share issues delisted in 2001. Further, in 2002 and 2003 only 14 and 10 issues, respectively, were delisted, followed by another 10 issues in 2004. This trend continued in 2005 and 2006 when 16 and 9 companies, respectively, were delisted, all of them based on the issuer's decision. Figure A.2 in the appendix and the following Table 2 provide a more comprehensive picture of delisting on the PSE.

Figures in this table confirm that massive delisting took place on the PSE especially in 1997 when almost $80 \%$ of all delisted companies left the market, most of

\footnotetext{
${ }^{23}$ Volume of the part of the issue released through public offer had to be at least USD 3.4 mil. and proportion of the issue released through public offer in the total volume of the issue at least $20 \%$. In addition the issuer had to be in business for at least two years (PSE Monthly Report, February 1997).

${ }^{24}$ The PSE claims that except for the above mentioned conditions also other factors were accounted for when deciding about delisting: value and frequency of direct and block trades, the structure of the company owners, providing information about the issuer and the security issue to the stock exchange and trading conducted at the international stock exchanges. Even though these criteria are mentioned by the PSE, it does not explain how they were taken into account.

${ }^{25}$ Admission to the main and secondary market required the issuer to be in business for a minimum of three years (before it was only two years). The disclosure duties on the free market were expanded.
} 
them due to insufficient liquidity. Such a sharp decline in the number of traded shares in conjunction with almost no new companies entering the market did not contribute to the desired development of the newly created market. This leads us to the investigation of the effects and determinants of delisting in transition economies which is lacking in the relevant literature. Our research thus helps answer the question if and how it could have been possible to prevent this situation and in this way ensure a more standard development of an emerging stock market.

Table 2: Reasons for delisting firms from the Prague Stock Exchange in 1993 - 2004

\begin{tabular}{|c|c|c|c|c|c|c|c|c|c|c|c|c|c|c|}
\hline REASON & 1993 & 1994 & 1995 & 1996 & 1997 & 1998 & 1999 & 2000 & 2001 & 2002 & 2003 & 2004 & 2005 & 2006 \\
\hline decision of the authority & & & 1 & 11 & 1210 & 1 & 65 & 4 & 13 & 7 & 2 & & & \\
\hline \multicolumn{15}{|l|}{ PSE } \\
\hline Ministry of Finance & & & 1 & & & & & & & & & & & \\
\hline \multicolumn{15}{|l|}{ decision not specified } \\
\hline sanction of the PSE board & & & & 1 & & & & 1 & 1 & & & & & \\
\hline trading group cancelled & & & & & & & 65 & & & & & & & \\
\hline insufficient liquidity & & & & 10 & 1210 & & & 1 & & & & & & \\
\hline $\begin{array}{l}\text { low liquidity and high } \\
\text { own. concentration }\end{array}$ & & & & & & & & & & 5 & & & & \\
\hline low marcap and liquidity & & & & & & & & & 9 & 2 & 2 & & & \\
\hline $\begin{array}{l}\text { low marcap, liquidity and } \\
\text { high own. conc. }\end{array}$ & & & & & & & & & 3 & & & & & \\
\hline information duties & & & & & & 1 & & 2 & & & & & & \\
\hline decision of the issuer & 6 & 7 & 12 & 37 & 10 & 6 & 11 & 14 & 17 & 5 & 8 & 10 & 16 & 9 \\
\hline issuer's request & & 2 & 4 & 1 & 2 & & & 1 & 2 & 2 & 5 & 10 & 9 & 3 \\
\hline end of public trading & 2 & & 3 & 29 & 7 & 6 & 11 & 13 & 15 & 3 & 3 & & & \\
\hline limited transferability & 4 & 5 & 5 & 7 & 1 & & & & & & & & & \\
\hline squeeze out & & & & & & & & & & & & & 7 & 6 \\
\hline bankruptcy related & 3 & 3 & 6 & 13 & 5 & 4 & 3 & 10 & 4 & 2 & & & & \\
\hline start of chapter 7 or 11 & & 1 & & 7 & 3 & 2 & 2 & 2 & 1 & 1 & & & & \\
\hline start of liquidation & & & & 1 & & & & 1 & 1 & & & & & \\
\hline liquidation & 3 & 2 & 6 & 5 & 2 & 2 & 1 & 7 & 2 & 1 & & & & \\
\hline Total delisted & 9 & 10 & 19 & 61 & 1225 & 11 & 79 & 28 & 34 & 14 & 10 & 10 & 16 & 9 \\
\hline $\begin{array}{l}\text { Delisted (\% of listed at } \\
\text { the beginning of year) }\end{array}$ & & 1 & 1,9 & 3,6 & 73,4 & 3,4 & 26 & 14,4 & 22,5 & 13,7 & 12,7 & 15,4 & 29,1 & \\
\hline
\end{tabular}

Source: Prague Stock Exchange and author's calculations

\section{Determinants of delisting}

Based on the above description of stock market development in the Czech Republic, we assume that there exist certain indicators according to which it would have been possible to predict delisting. Delisting only indicates an effort of the market mechanism to remedy the wrong decision of privatization authorities as the enterprises excluded 
from the public market were not natural candidates for public trading. Privatization is therefore the most important criterion when identifying the determinants of delisting in the Czech Republic. This approach sheds light on the structure of factors that played an important role in the delisting process and also indicates that certain determinants were decisive from the very beginning i.e. it was possible to account for them even in the preprivatization period. Factors connected to privatization are important because they are connected to the concentration of ownership. If the pre-privatization and privatization determinants turn out significant, it could indicate that the decision to place all the privatized companies on the stock exchange when the stock market was not functioning yet and could not bear such a high number of securities, was not the best one from the point of view of stock market development.

Based on the above description, we could consider delisting a function of the following three groups of factors:

$$
\text { delisting }=f(\text { pre _ priv; priv; post_priv) }
$$

The first group covers pre-privatization characteristics (pre_priv) of the companies, the second is related to the privatization process (priv) and the third one concerns postprivatization (post_priv) factors ${ }^{26}$.

\section{- PRE-PRIVATIZATION FACTORS}

These factors contain general characteristics of companies prior to privatization. They include the industry to which a given company belongs ${ }^{27}$, the size of the company as well as indicators of its financial "health". We measure the size of the company by the number of employees as well as the total number of the company's shares ${ }^{28}$. Larger companies are expected to be less prone to delisting as their size makes them more natural candidates for public trading. Moreover, it should be much harder to obtain a controlling share in a big company. For financial indicators we have available the indicators of sales, profit and debt scaled by the company's capital. These are available for the three years before the privatization took place. However, all of these indicators are based on socialist accounting practices which do not necessary provide a true picture

\footnotetext{
26 This qualification of determinants is based on the timing of information and therefore we do not consider interactions between these factors.

${ }^{27}$ We use PSE classification.

${ }^{28}$ Equal to company's book value since the nominal value of original shares was $1000 \mathrm{CZK}$.
} 
of a company's situation. This will be taken into account when discussing the results of our estimations.

\section{- PRIVATIZATION FACTORS}

This set of delisting determinants relates to the privatization process and its aftermath. We distinguish two privatization waves while also taking into account the companies that were privatized in both of these waves. An important source of information is the privatization project that was prepared by the managers of each company before the actual privatization took place and that was finally accepted. Here the expected ownership structure was indicated and we use the data concerning shares of the company owned by the National Property Fund (NPF). A higher NPF ownership share indicates the interest of state in a given company. The reasons leading to this decision ranged from the intention of the state to implement necessary structural changes in a given company to preventing the company from misusing its monopoly position (NPF Annual Report 1995). As the objective of the NPF was to show how well capital market works and thus keep its companies publicly tradable, the probability of delisting in these cases was rather low.

The attractiveness of certain companies in the privatization process is reflected in the average price for which shares were sold in the auctions. Companies with a better future outlook and thus with a lower probability of being delisted should be characterized by a relatively higher average price for their shares. Different proportions of companies' assets were offered in mass privatization, a factor that is reflected by the ratio of the number of shares in mass privatization to total number of shares. The ownership structure that arises right after the privatization is crucial for further development of the company. The proportion owned by individuals as well as investment privatization funds is expected to play a role here.

\section{- POST-PRIVATIZATION FACTORS}

We first consider the development of the financial indicators after privatization and the consolidation of the ownership structure as these could reveal companies that would most likely be delisted. The indicators that are investigated include sales, profit, operational profit, total liabilities and value added, all scaled by total assets. Moreover, the sales variable is used to calculate growth opportunities for a company, defined as the 
growth rate between the current and following year of average sales in a given industry, excluding the company itself. The same calculation is applied to the operational profit data to obtain the potential profit figure.

Further, trading on the stock exchange should also be taken into account. One of the main trading characteristics is the frequency of trading of the stock. Even if this indicator is low, it does not have to lead to delisting on the developed market because it only indicates that the distribution of beliefs is the same among traders. In the Czech case, however, a low frequency of trading was one of the conditions for delisting set by the PSE. On the other hand, a high frequency of trading can be considered a good signal, particularly if this trend persists over time. An irregular pattern of trading intensity can indicate either a consolidation of ownership structure following mass privatization or an attempt to influence the price and consequently a potential tender offer price for minority shareholders (Atanasov et al., 2005). In this respect the development of price and price differentials can help to clarify the situation. Another feature of trading is trading in blocks. If there are many block trades that significantly influence the price, there is a probability of price manipulation leading to tunneling and further delisting. Nevertheless, the usage of trading characteristics as determinants of delisting can cause difficulties in the estimations because of the possible endogeneity problem. This problem arises if we assume that the market is functioning properly in a sense that it already takes into account the fact that some of the privatized companies should not be listed on the stock exchange. If this assumption holds, the fact that the frequency of their trading is low just indicates that the market expects these companies to be delisted and thus the endogeneity problem is present. Nonetheless, we will estimate the model in a reduced equation form in which simultaneous effects will not be taken into account. Therefore we will consider only the determinants of delisting that do not concern trading on the stock exchange.

In comparison to our previous discussion, the official reasons for delisting provided by the responsible authorities are rather general ${ }^{29}$. Table 2 in section 2 provides them in more detail. It shows that the most important reasons for excluding

\footnotetext{
${ }^{29}$ In this respect it is important to note that the time of delisting also plays a role here. The later a certain security was delisted, the more precisely the reasons for its delisting were defined. In fact, in 1997 when the highest number of firms was delisted the appropriate reasoning was not provided for all the delisted companies.
} 
firms from public trading in the Czech Republic are based on the decision of the authorities, mostly the PSE. The most commonly mentioned reason is insufficient liquidity of securities (about $80 \%$ of delisted securities). Then, the end of public trading based on the decision of the issuer follows (about $6 \%$ of delisted companies) and more than $4 \%$ of companies were delisted in 1999 when their trading group on the PSE was cancelled. The number of companies delisted due to other reasons is relatively insignificant when we consider them in relation to all 1510 delisted companies. It is thus clear that the reasons for delisting provided by the PSE are not sufficient in order to explain the phenomenon of delisting and a more careful investigation is necessary.

\section{Methodology}

Delisting is modeled as a zero-one phenomenon, i.e. the company is still traded on the stock exchange (0) or it is delisted (1). We estimate a linear probability model where the dependent variable is the probability of delisting. It equals one for the companies that were delisted. The explanatory variables belong to the three groups of factors described in the previous section (equation 1) and thus the estimated model has the following form:

$$
P(y=1)=\alpha+\beta \cdot \text { pre }{ }_{-} \text {priv }+\gamma \cdot \text { priv }+\delta \cdot \text { post } \_ \text {priv }
$$

We also take into account possible connections between variables in different groups. It has already been mentioned that the average share price in a privatization auction reflects the attractiveness of a given company for investors. Thus, if we assume that the market functions well and the future prospects of a company are already included in this price, the post privatization profit variable could be connected to the average price. This could lead to an endogeneity problem and spoil our results. To account for this problem, we use the growth in sales and the growth in operational profit instead of plain operational profits and sales as indicators of the post-privatization development. Both of them are defined as the growth rate between the current and the following year of average value in a given industry, excluding the company itself. As the company under consideration is not included in the construction of these indicators, we consider their usage appropriate to solve the possible endogeneity problem. Furthermore, these indicators are suitable to describe the post-privatization development. Growth in sales 
accounts for the opportunities the company has in its own industry and the operational profit variable shows the profitability i.e. resources available inside the companies. The actual model that we finally run on the whole data sample has the following specification:

$$
\begin{aligned}
P(\text { del }=1)= & \alpha+\beta_{1} \cdot \text { tns }+\beta_{2} \cdot n p f+\beta_{3} \cdot \text { prof_tns }+\gamma_{1} \cdot a p+\gamma_{2} \cdot a p^{2}+ \\
& +\gamma_{3} \cdot \text { wave }+\gamma_{4} \cdot \text { both }+\delta_{1} \cdot \text { opro_gr }+\delta_{2} \cdot \text { sales_gr }+\delta_{3} \cdot \text { mills }
\end{aligned}
$$

where

- $\quad$ del is a dummy variable that equals 1 for the company that was delisted and 0 for not-delisted

- $\quad$ tns is total number of shares of a company (in millions of shares)

- $\quad n p f$ is the share of the company owned by the National Property Fund that was indicated in the company's privatization project

- $\quad$ prof_tns is profit per share one year before privatization

- $\quad a p$ is average price of a company's shares in the privatization auction (in points)

- wave stands for a dummy indicating the privatization wave in which a given company was privatized

- $\quad$ both is a dummy variable that equals one for companies privatized in both waves

- opro_gr is growth in operational profit defined as the growth rate of average operational profit in the industry (between 1996 and 1997), excluding the company itself

- $\quad$ sales_gr stands for growth opportunities, defined as the growth rate of average sales in the industry (between 1996 and 1997), excluding the company itself

- $\quad$ mills is the inverse Mills ratio ${ }^{30}$

This inverse Mills ratio enables us to account for the missing financial data problem. Even though our sample contains all the companies privatized under the voucher privatization scheme, we face the problem of missing observations, due to the fact that not all the companies were willing to report their financial results. This was possible because market supervision as well as law enforcement after privatization were weak. The presence of missing observations leads to a sample selection bias problem that we

\footnotetext{
${ }^{30}$ It is the ratio of the probability density function for the standard normal over its cumulative density function.
} 
address by employing a two stage estimation (Heckman, 1979). The main part of this estimation constitutes the linear probability model described above. In order to obtain the inverse Mills ratio for this model we investigate the firms that do not report information about their profits before and after the privatization and consider the factors determining their decision. This approach is a Heckit regression where we employ probit estimation in the first stage and a linear probability model in the second. We have chosen a linear probability model for several reasons. Firstly, it allows to instrument for profit and in comparison to logit it provides consistent estimates under standard assumptions (Angrist and Krueger, 2001). Moreover, the linear probability model can be corrected for sample selection.

The probit regression, with the dependent variable being missing financial data as a binary response, that we estimate first has the following form:

$$
P(\text { sel }=1)=\text { const }+\alpha \cdot \text { size }+\beta \cdot \text { owner }+\gamma \cdot \text { ipf }+\delta \cdot \text { ind }+\omega \cdot \text { miss }
$$

where size accounts for the size of the company ${ }^{31}$ and its proportion privatized in the mass privatization. The set of variables concerning the ownership structure (owner) described in the privatization project includes dummies for domestic and foreign owners as well as restitutions, National Property Fund share, municipalities and selling via intermediaries. IPF stands for the actual ownership shares owned by the investment privatization funds following the privatization. We further account for the industry to which a given company belongs (ind $)^{32}$. Moreover, we define a dummy variable based on the firm's reporting or non-reporting in the pre-privatization period (miss). If a company has not reported some of its financial indicators before ${ }^{33}$, we believe that there is a high probability that it will continue doing so also after privatization.

Except for this basic two stage model where we only distinguish between delisted and not delisted share issues, we also employ a more precise classification of companies. It concerns the three main reasons for delisting: decision of the authority, decision of the issuer and bankruptcy related reasons. The determinants of delisting may be different for each of these subgroups. The results of a preliminary investigation

\footnotetext{
${ }^{31}$ We also add quadratic term to this variable, since we expect the relationship to be nonlinear.

${ }^{32}$ We use PSE classification.

${ }^{33}$ At least two out of the three pre-privatization indicators are missing in our sample.
} 
confirm that the proportions of missing observations are not significantly different when accounting for different delisting reasons (see Table A.8 in the appendix) and therefore there is no need to estimate the model in two stages as the one above where we only distinguished between delisted and not delisted companies. Rather, we run multinomial logit estimation based on a similar model specification as before (equation 3), where the dependent variable takes four different values. They account for not delisted firms, firms delisted due to decision of the authority, issuer and bankruptcy respectively.

Besides the binary regression model, another possibility to estimate delisting is survival analysis employing a hazard model. The dependent variable in this case is time elapsed until a given company becomes delisted. However, the fact that delisting in most cases occurred in the waves can cause problems with identification of such a model. The actual date of delisting is not that important for this analysis and moreover, it may even be affected by other factors of a mainly technical and administrative nature. Therefore, we prefer to conduct the analysis by using several variations of the binary regression model instead.

\section{Data description}

Our data set includes the population of firms privatized in the first and the second wave of the mass privatization program. Altogether it contains 1664 medium and large nonfinancial companies that traded on the Prague Stock Exchange following privatization. The time period under consideration is the whole transition period from $1992-2004$. Data concerning privatization come from the Ministry of Privatization of the Czech Republic as well as from the Ministry of Finance (privatization projects, preprivatization data). The data on holdings after the first and second privatization wave come from the Prague Securities Centre database. Financial data, together with the postprivatization ownership structure of the companies are from the private database $\mathrm{ASPEKT}^{34}$ which is based on the annual reports as well as information provided to the stock exchange and companies' shareholders. Finally, the Prague Stock Exchange provided data about delisting. Details concerning changes in the legal status of delisted companies (bankruptcy, merger, acquisition) were taken from the Czech companies

\footnotetext{
${ }^{34}$ ASPEKT database is a Czech source for AMADEUS, a pan-European database containing financial statements data. All financial statements in our data set are audited.
} 
register ${ }^{35}$. Description of the variables used in the estimation is provided in Table A.9 in the appendix.

\subsection{Descriptive statistics}

Different characteristics of the companies are investigated for the whole sample as well as for the subcategories of delisted and not delisted companies. Differences between these subsamples are tested using nonparametric tests ${ }^{36}$. Furthermore, in the delisted subgroup we distinguish the waves of delisting as well as the different reasons for which the companies were delisted. Descriptive statistics show that the data for all the companies and subgroups included in the analysis are characterized by a very high degree of variability. This pattern is especially visible when considering median and quartile coefficients ${ }^{37}$.

Pre-privatization firm size is measured by the number of employees as well as the total number of firm's shares in the voucher privatization (see Table A.3 in the appendix). The absolute number of employees decreases for both delisted and not delisted subgroups with approaching privatization. This decrease is more significant for the delisted companies and within this subgroup especially for companies that were delisted due to bankruptcy. The general decrease in the number of employees before privatization can be attributed to the overall transition process and restructuring, which was taking place at the beginning of the 1990s. The difference between the number of employees three years and one year before privatization shows the dynamics of the ongoing restructuring. Analysis of the number of employees variable, however, faces a problem of missing observations, with the number of observations three years before privatization much lower in comparison to what is available for one year before privatization. Furthermore, the data concerning the number of employees for the firms included in our sample is not available for the period after privatization. Therefore, we focus on the total number of shares which reflects the capital or "book value" of a given company as our size measure. Moreover, thanks to this pre-privatization measure we

\footnotetext{
${ }^{35}$ www.justice.cz. By further existence we mean existence of the company's capital. Therefore if a company merged with some other company, its capital is still in use and we consider this acceptable for our purposes.

${ }^{36}$ We have used nonparametric K-sample test on the equality of medians and the Wilcoxon ranksum test. We do not provide the exact outcomes of these tests here but they are available upon request.

${ }^{37}$ Detail results are not part of this paper but are available at http://home.cerge-ei.cz/fungacova.
} 
can use the total assets variable for the after privatization period because it basically measures the same thing as the total number of shares variable. The total number of shares indicator, similar to the number of employees variable, shows that delisted companies are significantly ${ }^{38}$ smaller than their counterparts that remain listed on the stock exchange. Companies delisted based on the decision of the authority are smaller than companies delisted for other reasons. This result indicates the effort of the PSE to consolidate the situation on the stock exchange and correct the wrong administrative decision of placing all the privatization companies' shares on the public market. Moreover, companies delisted in the four main waves in 1997 and before are significantly smaller than the ones delisted afterwards. Results for the total number of shares variable thus confirm our expectation that the size of a company measured by the amount of the company's capital is an important predictor of delisting, as shown in the results found for Bulgaria (Atanasov et al., 2005). This trend is also visible when considering the distribution of companies listed on the PSE by size (Figure A.3 in the appendix).

On the other hand, the pre-privatization financial characteristics (sales, debt, and profit) do not differ significantly for the subgroups of companies that we consider (see Table A.4 in the appendix). This could be attributed to the fact that restructuring was only beginning in the early 1990s as there was no private ownership at that time. Consequently, its effect cannot yet be visible in the financial indicators. Another possible explanation is that this data is based on socialist accounting practices which were different from western standards, reflecting the amount of production rather than the profitability of the companies ${ }^{39}$. Nevertheless, the amount of debt increases for companies that are not delisted as the time of privatization approaches. This could indicate their effort to restructure. It is important to note, however, that the number of observations of debt available in our sample is lower than for the other financial indicators, meaning that not all the companies were willing to provide this information to the public. Similar to debt, the profit variable also worsens for all the companies as privatization draws nearer. Profit, especially, decreases one year before privatization starts. This trend can most probably be attributed to the overall transition process and

\footnotetext{
${ }^{38}$ Nonparametric K-sample test on the equality of medians and the Wilcoxon ranksum tests mentioned above confirm these results.

${ }^{39}$ For more details see Filer and Hanousek (2002).
} 
the abrupt changes that were going on in the economy at that time. However, the difference between sales three years and one year prior to privatization shows a significant difference between subsequently delisted and not delisted companies. Even though sales tend to increase for both subgroups, the increase for companies that were not delisted was significantly higher.

The average price of shares in the privatization process (see Table A.5 and Table A.6 in the appendix) was significantly higher for companies that were not delisted (see also Figure A.4 in the appendix), indicating that these companies were more attractive to investors. Within the delisted subgroup, the average price is higher for companies delisted after 1997. All of these findings show that bidders in the privatization process were able to distinguish between "good" and "bad" companies and evaluate the future prospects of a given company. Companies delisted based on the decision of the issuer exhibit higher average price than those delisted for other reasons. The fact that they were delisted despite a relatively high average price may indicate that the owners themselves found that there is no reason for having company shares publicly traded due to the company's size and other company characteristics. On the other hand, one could speculate that the delisting decision of owners may also indicate possible tunneling in a given company.

Furthermore, when distinguishing the wave in which a given company was privatized, a difference in average price between the delisted and not delisted subgroups is apparent. The average price is significantly higher for the companies that belong to the second wave. The difference between the first and second wave may be attributed to the fact that the investors might have already acquired experience while bidding in the first privatization round. Moreover, the stock exchange had already been established by the time of the second wave and was functioning as a kind of bridge between the real and the "fictive" i.e. voucher point price based on the socialist accounting standards.

The privatization factors that we consider also include variables describing the ownership structure that arose right after privatization. Investment privatization funds' holdings differ significantly after the second privatization wave for all the subgroups of companies that we consider (see Table A.7 in the appendix). Funds' holdings are higher for delisted companies, which indicates that there was a higher probability of funds' owners exercising their power over the companies. When accounting for time of 
delisting, the results indicate that funds' holdings in companies delisted in and before 1997 are higher in comparison to the rest of the delisted companies. The reason for the significant differences only in the second wave holdings could be the announcement that the second privatization wave was the last one which made investors who were really interested in a particular company obtain as many of its shares as possible.

The third group of indicators concerns the period after privatization. We consider the following post-privatization financial characteristics: profit, operational profit and its growth, sales and their growth, total assets, total liabilities and value $\operatorname{added}^{40}$. Similar to our expectations, the above described nonparametric tests that we apply confirm that these characteristics are significantly different for delisted and notdelisted companies, as well as for the reasons and time subgroups within the delisted group.

\section{Estimation and results}

In order to estimate the influence of different factors on delisting we run the above described two stage Heckit regression on the sample including all companies ever listed on the PSE. The linear probability model (equation 3) provides us with the results summarized in the Table 3 below.

All the explanatory variables included in the model with the exception of the pre-privatization profit indicator are significant. Moreover, the estimated effects exhibit the expected signs. There are two possible explanations for the non-significance of the pre-privatization profit. The first one is connected to the already mentioned quality of the data from the pre-privatization period. The indicator of profit in this case does not reflect profit but production and therefore does not necessarily reveal the true picture of the situation in a given company. The other explanation is the possibility of tunneling.

The significance of other factors indicates that delisted companies exhibited, before and during the actual privatization, different characteristics from the companies that remained on the stock exchange. The size of the company (measured by the total number of shares) and the ownership structure described in the privatization project have played a major significant here. These results confirm our expectations with larger

${ }^{40}$ Similar to the previous cases detail results are not part of this paper but are available at http://home.cerge-ei.cz/fungacova. 
companies having a lower probability of being delisted. A one standard deviation change in the size of company measured by total number of shares, decreases probability of delisting by 4 percent (the last column in above Table 3). More specifically, this result suggests that the increase in the size of company by a million shares decreases the probability of delisting by 2.26 percent. The significance and magnitude of the results indicate that, as we have argued earlier, not all the companies privatized in voucher privatization were suitable candidates for immediate placement on the stock exchange. Size of the company could have been considered one of the decisive factors for the necessary filtering to prevent the emergence of a nontransparent market.

Table 3: Linear probability model for delisting ( $\mathrm{y}=1$ for delisting)

\begin{tabular}{|l|c|c|c|}
\hline & Linear probability model & Interpretation \\
\hline Pre-privatization factors & $\begin{array}{c}\text { Estimated } \\
\text { coefficient }\end{array}$ & $\begin{array}{c}\text { Standard } \\
\text { Error }\end{array}$ & $\begin{array}{c}\text { Overall effect (one st. } \\
\text { deviation change) }\end{array}$ \\
\hline Total number of shares (millions of shares) & $-0.0226^{* *}$ & 0.010 & $-4 \%$ \\
Profit before privatization (scaled by book value) & $6.5 \mathrm{E}-06$ & 0.0003 & $0.01 \%$ \\
\hline Privatization factors & $\begin{array}{c}\text { Estimated } \\
\text { coefficient }\end{array}$ & $\begin{array}{c}\text { Standard } \\
\text { Error }\end{array}$ \\
\hline National property fund ownership & $-0.003^{* * *}$ & 0.001 & $-4.26 \%$ \\
Average price in voucher auction (in points) & $-0.001^{* * *}$ & 0.0003 & $-5.66 \%$ \\
Average price (squared) & $1.1 \mathrm{E}-06^{* * *}$ & $2.5 \mathrm{E}-07$ & $0.31 \%$ \\
Average price (overall effect) & & & $-5.35 \%$ \\
Privatization wave & $-0.055^{* * *}$ & 0.015 & \\
Privatized in both waves & $-0.057 * *$ & 0.028 & \\
\hline Post-privatization factors & Estimated & Standard & \\
\hline Operational profit growth & coefficient & Error & \\
Growth opportunities (sales) & $-0.0001 * * *$ & $3.9 \mathrm{E}-05$ & $-2.65 \%$ \\
Mills ratio (sample selection) & $0.006 * * *$ & 0.001 & $4.31 \%$ \\
\hline Constant & $0.353 * * *$ & 0.087 & \\
\hline Number of observations & $0.885 * * *$ & 0.027 & \\
Adjusted $\mathrm{R}^{2}$ & \multicolumn{1}{|c|}{1,470} & & \\
\hline
\end{tabular}

Note: The table contains estimation results for the linear probability model. We report estimated coefficients as well as their significance (* significant at 10\%, $* *$ significant at 5\% and $* * *$ significant at $1 \%$ ). In the linear probability model estimated coefficient correspond to the marginal effect.

In addition to company size, the proportion of shares held by the National Property Fund (NPF) could serve as a predictor of possible delisting. Our results show that an increase in the amount of shares owned by the NPF by one percent decreases the 
probability of delisting by 0.3 percent, which in the one standard deviation change measure makes as much as 4.3 percent. This is because the state tends to play a special role in the ownership structure and in this case it also indicates the future intensions of state towards the privatized company ${ }^{41}$. Another important privatization factor is the average price of the privatized companies' shares. As we expect to find a nonlinear relationship between average price and delisting, average price is also included in quadratic form. A higher price indicates a higher valuation of the company by bidders ${ }^{42}$ and thus, greater expected future prospects and lower probability of being delisted. The results of our estimation support this hypothesis. An increase in the average price by ten voucher points decreases the probability of delisting by 1 percent. A one standard deviation increase in price decreases the probability by 5.35 percent. Thus, the average price in the voucher auction turns out to be one of the most important predictors of delisting.

Another decisive factor is the privatization wave in which a given company was privatized. Our results suggest that the probability of delisting is 5.5 percent lower for companies that were privatized in the first privatization wave and 5.7 percent for those that were privatized in both waves. This result is in line with findings of Gupta et al. (2000) who provide evidence that the more profitable firms were privatized first in the Czech Republic.

Massive delisting took place in 1997, and thus also post-privatization company characteristics are expected to influence delisting. We consider operational profit which is, in comparison to the pre-privatization profit, based on standard accounting practices and, unlike the overall profit variable, better reflects the real functioning of a given company because it does not include extraordinary items. The years under consideration are 1996 and 1997; this time period directly follows privatization and at the same time precedes the main waves of delisting. As already mentioned, due to a possible connection between profit and the average price in the privatization auction we construct an operational profit growth variable based on the operational profit growth in a given industry. Its estimated coefficient is significant and its sign indicates that

\footnotetext{
${ }^{41}$ Most of the companies where the state owned a significant proportion of shares were so called strategic companies.

${ }^{42}$ Hanousek and Filer (2001) show that prices of larger firms comprising the bulk of assets in the voucher privatization scheme rapidly incorporated all the public as well as private information.
} 
decrease of growth in operational profits by one percent increases the probability of delisting by 0.01 percent, which in the standard deviation change measure translates into 2.65 percent. This result corresponds to our expectations, even though the effect is not as strong as in the case of pre-privatization and privatization factors, which play a key role in explaining delisting.

The estimated model also considers future prospects of a listed company. We include a forward looking indicator that accounts for a company's growth opportunities. As described in the methodology section, it is based on the growth of sales in a given industry. Similar to our expectations, the estimated coefficient is significant. One would expect it to have a negative sign, so that probability of delisting would decrease with higher growth opportunities. It is however, positive, and one standard deviation increase in the growth opportunities constitutes a 4.3 percent increase in probability of delisting. This means that future prospects play a role in delisting but our result also suggests that the new owners can, despite a promising future, exercise their power and tunnel the company.

The inverse Mills ratio turns out to be significant, which suggests that the unwillingness to report financial results plays a role in the delisting process and the two stage estimation procedure is necessary. $\mathrm{R}^{2}$ as a measure for goodness of fit is not very high, however, taking into account the structure of the model and a relatively high number of delisted companies it cannot be much higher. We employ a McNemar-type of test suggested by Hanousek (2000) to compare our model to a naive estimator on the basis of their predictive accuracy. This can be interpreted as a test of the significance of the model. The quality of prediction is summarized in Table A.10 in the appendix and the corresponding high value of $\chi^{2}$ confirms that our estimator dominates the naïve estimator in terms of prediction accuracy ${ }^{43}$. Thus, the estimated model is significant and supports our hypothesis, that there exist several economic measures, especially from the pre-privatization and privatization period, based on which delisting of certain companies could have been predicted and that could have been used when deciding which companies to place on the stock exchange for public trading after the voucher privatization.

\footnotetext{
${ }^{43}$ Formally we reject the null hypothesis that the probability of correct prediction is the same for both models.
} 


\subsection{Reasons for delisting}

Besides distinguishing between delisted and not delisted companies, we also account for the reasons for delisting. There are three main categories of reasons for delisting from the PSE: decision of the authority, decision of the issuer and bankruptcy related reasons. We deem it important to examine the determinants of delisting for these categories and as explained in the methodology section we employ a multinomial logit model to do it. It has the form of the basic model (equation 3) without Mills ratio but the dependent variable is different in this case. It can take four different values:

- 0 for companies that were not delisted

- 1 for companies delisted based on the decision of the authority

- 2 for companies delisted on the issuer's request

- 3 for bankruptcy related delisting

Table 4: Multinomial logit model based on different reasons for delisting

\begin{tabular}{|c|c|c|c|c|c|c|}
\hline \multirow{2}{*}{$\frac{\text { MULTINOMIAL LOGIT }}{\text { Pre-privatization factors }}$} & \multicolumn{2}{|c|}{ Decision of the authority } & \multicolumn{2}{|c|}{ Decision of the issuer } & \multicolumn{2}{|c|}{ Bankruptcy related } \\
\hline & coefficient & $\mathrm{dP} / \mathrm{dX}$ & coefficient & $\mathrm{dP} / \mathrm{dX}$ & coefficient & $\mathrm{dP} / \mathrm{dX}$ \\
\hline Total number of shares (millions) & $-2.3451 * * *$ & -0.296 & 0.003 & 0.127 & 0.046 & 0.05 \\
\hline $\begin{array}{l}\text { Profit before privatization } \\
\text { (scaled by book value) }\end{array}$ & -0.0031 & 0.001 & -0.034 & -0.002 & -0.0005 & 0.0002 \\
\hline \multicolumn{7}{|l|}{ Privatization factors } \\
\hline National property fund ownership & -0.003 & 0.002 & $-0.035 * * *$ & -0.002 & $-0.022 *$ & -0.0004 \\
\hline Average price (in points) & $-0.016 * * *$ & -0.002 & 0.003 & 0.001 & -0.007 & 0.0001 \\
\hline Average price (squared) & $2.8 \mathrm{E}-05 * *$ & 5.9E-07 & $-1.2 \mathrm{E}-05$ & $-2.0 \mathrm{E}-06$ & -0.0001 & $-3.0 \mathrm{E}-06$ \\
\hline Average price (together) & & -0.002 & & 0.001 & & -0.0003 \\
\hline Privatization wave & $-1.081 * * *$ & -0.13 & -0.118 & 0.049 & 0.111 & 0.026 \\
\hline Privatized in both waves & $-0.695 * *$ & -0.082 & -0.325 & 0.012 & 0.584 & 0.033 \\
\hline \multicolumn{7}{|l|}{ Post-privatization factors } \\
\hline Growth opportunities (sales) & $0.053 * * *$ & 0.004 & 0.030 & -0.001 & $0.047081 *$ & 0.0002 \\
\hline Operational profit growth & $-0.001 * *$ & -0.0001 & -0.0003 & 0.0001 & $-0.002 * *$ & $-3.2 \mathrm{E}-05$ \\
\hline Constant & $3.758 * * *$ & 0.491 & 0.041 & -0.196 & $-1.051 *$ & -0.11 \\
\hline Number of observations & \multicolumn{6}{|c|}{1,656} \\
\hline Scaled $\mathrm{R}^{2}$ & \multicolumn{6}{|c|}{0.245} \\
\hline
\end{tabular}

Note: The table contains estimation results for the multinomial logit model where reasons for delisting are taken into account. The results for not delisted companies are not reported (it is possible to count them based on these numbers as the sum of probabilities equals 1). We report estimated coefficients, their significance (* significant at $10 \%, * *$ significant at $5 \%$ and $* * *$ significant at $1 \%$ ) as well as marginal effects $(\mathrm{dP} / \mathrm{dX})$ for the particular reasons for delisting. 
The estimation results uncover differences between groups of companies delisted due to different reasons. As Table 4 shows, the most significant results are obtained for the subgroup delisted due to the decision of the authority. This result is most probably also due to the size of this subgroup, as it contains as many as 1200 observations (which comprise $82 \%$ of the whole sample). The results for companies delisted due to the decision of the authority are in line with the results obtained for the basic model. The marginal effects that are reported stress the importance of company size, which is the most influential determinant of delisting because the probability of delisting decreases by $30 \%$ when increasing the number of shares by one million. Nevertheless, unlike the basic model, the coefficient for the National Property Fund (NPF) variable is insignificant here. This may indicate that the significance of the NPF variable in the basic model was primarily driven by the companies that were not delisted. However, when we distinguish subgroups of companies in more detail, the effects across them differ and the NPF variable becomes significant even for smaller subgroups.

Yet, the effect of a lower number of observations is visible on the significance of the other coefficients for companies delisted in the other two subgroups. When interpreting these results there is another issue that needs to be taken into account; companies delisted based on the issuer's request can be of two types. The first one is represented by the companies that are objectively, especially due to their size or area in which they operate, not appropriate candidates for public trading and their owners decided to delist in order to correct the wrong administrative decision that followed voucher privatization. On the other hand, there are companies that their owners wanted to delist because they did not want to disclose information about the company to the public. These two issues then contribute to splitting this subgroup containing a relatively low number of observations even more and consequently it is not possible to expect any significant results. Despite this fact, as we have already mentioned, the ownership share of the NPF plays a significant role in the decision of the issuer subgroup. Increase of the share owned by the NPF by one percentage point decreases the probability of delisting by 0.2 percent. This result only confirms that companies where NPF has an ownership share are not expected to be delisted, especially if the reason for delisting is the decision of the issuer. The strong position of the NPF is visible also in the subgroup delisted due to bankruptcy, where the NPF ownership 
variable is significant as well but its effect is much smaller (0.04 percentage points). The most important variable for the bankruptcy related subgroup is the operational profit growth variable. This is exactly what one would expect; as operational profit is a crucial indicator of a company's functioning. Even though its effect is significant, it is not very high. Thus, despite the fact that not all the results in this specification turn out to be significant, there are visible trends that confirm differences between companies delisted due to different reasons that are in line with our expectations and previous estimations.

Defining reasons for delisting based on the information we have available is rather difficult and thus it is possible to view it from several different perspectives. In the estimations conducted above we were mostly considering the reasons provided by the stock exchange. The most common reason for delisting defined by the stock exchange was insufficient liquidity. Until now we have treated it as a decision of the authority. In the alternative classification we consider companies delisted because of the insufficient liquidity to be part of the group delisted due to the decision of the issuer. This is because insufficient liquidity indicates the presence of a dominant owner, who in case he does not want his company to be publicly traded in fact does not have to do anything. Since the free float is low, he is only waiting until the company is delisted because of insufficient liquidity. This further opens a discussion about delisting de facto and de jure. Delisting de jure is the official delisting reported by the stock exchange, while delisting de facto concerns the real behavior of the issuers. When taking delisting de facto approach, delisting due to insufficient liquidity can be considered a decision of the issuer. As a part of sensitivity analysis, we consider an alternative division of companies based on the de facto delisting approach and run the multinomial logit model described above on the new subgroups. The estimation results correspond to the ones already reported. The most significant results are obtained for the subgroup with the highest number of observations and the signs and magnitudes of the estimated coefficients are in line with the results of our basic model. The results for the subgroup of companies delisted due to bankruptcy, which stays the same as in the original division, remain basically unchanged. All of this thus reconfirms our previous results. 


\subsection{Robustness check}

All of the above-described estimations have also been carried out on the subsample that includes companies that were delisted in 1997 in the four major waves as well as those that have survived 1997. The companies in this subsample are the most important ones from the point of view of delisting as this phenomenon was relatively rare and insignificant before 1997. The estimations on this subsample have shown the same pattern of results as were described for all companies. In this way we have in fact used this subsample to check the robustness of our results.

Furthermore, we have also included industrial dummies in the linear probability model estimated as the second stage of Heckit regression. The industrial dummies were defined rather broadly and we only distinguish between heavy and light industries. Even when including these dummies, the estimated coefficients of other explanatory variables remained basically unchanged, which once again confirms the robustness of our results.

\section{Conclusion}

In its short history the Czech stock market, unlike the Polish or Hungarian ones, experienced massive delisting of shares and virtually no initial public offerings. Nevertheless, delisting in the Czech Republic was necessary due to the fact that all the privatized companies were simply placed on the market by an administrative decision following the voucher privatization. Interestingly enough, apart from the Czech Republic, massive delisting was also observed in other transition countries ${ }^{44}$ where the initial background was similar to the Czech one: voucher privatization. Massive delisting in conjunction with almost no new companies entering the market did not contribute to the development of these markets. Accordingly, all of them seem to lag behind the other transition countries (Fungáčová and Hanousek, 2006).

In this paper we investigate the determinants of delisting and point out that it was possible to prevent this situation. The results of our estimation indicate that there exist several factors based on which it was possible to identify companies that were going to be delisted even before the actual delisting took place. These characteristics include the size of the company, ownership share of the National Property Fund,

\footnotetext{
${ }^{44}$ Even though the developments in transition countries differed, besides Czech Republic delisting took place in Bulgaria, Lithuania and Slovakia.
} 
average price of company shares in the privatization process, privatization wave as well as a company's future prospects. Furthermore, a company's non-reporting in the preprivatization period plays a role in the delisting process as well. Most of these determinants of delisting are connected to the pre-privatization and privatization period. This means that it could have been possible to prevent delisting if these issues had been taken into account when deciding which companies to place on the stock exchange for public trading following the voucher privatization. Taking into account the overall development on the PSE we conjecture that massive delisting did not only serve to correct the wrong decision of the privatization authorities by "cleaning" the market of unsuitable shares but it also sent a signal concerning the functioning of the whole market. Cleaning itself had a positive effect in the long run because the market became more transparent. Nevertheless, in the short run delisting seems to have had a negative effect on the price development and the size of the market.

This development suggests that governments making important decisions concerning privatization programs and influencing emerging stock markets should be very careful when choosing which companies will be privatized, what method will be used and by which criteria these companies will be placed on the stock exchange. If a proper filtering of companies had been implemented in the Czech Republic before placing privatized companies on the stock exchange, a more transparent stock market fulfilling its main economic functions would have emerged after the privatization. This result can also be supported by comparing the Czech market to its counterparts in Poland and Hungary where the stock market evolved gradually and there was no massive delisting of shares. By taking into account their development one could speculate that massive delisting in the Czech Republic was one of the decisive factors causing the fact that there were virtually no new listings on the PSE. Then, with only a few liquid securities, there were not enough investment opportunities either for foreign, or domestic investors. This is important especially with respect to the ongoing pension system reform because the pension funds are usually required to invest some portion of their portfolio on the local market. If there are no suitable share issues available, they may end up buying only government bonds and investing more abroad, meaning that their economy could be deprived of this capital and they will in fact be financing the 
growth of some other country. Such an unfavorable development may, based on recent empirical studies, have implications for the country's further economic growth. 


\section{REFERENCES}

Angrist J. D., Krueger A. B. (2001): "Instrumental Variables and the Search for Identification: From Supply and Demand to Natural Experiments," Journal of Economic Perspectives, Volume 15(4): $69-85$.

Atanasov V., Ciccotello Conrad S., Gyoshev Stanley B. (2005): "How Does Law Affect Finance? An Empirical Examination of Tunneling in an Emerging Market," William Davidson Institute Working Paper No.742.

Bakker M., Gross A. (2004), "Development of Non-bank Financial Institutions and Capital Markets in European Union Accession Countries," World Bank Working Paper No. 28

Beck T., Levine R. (2003): "Stock Market, Banks and Growth: Panel Evidence," Journal of Banking and Finance, Volume 28 (3): 423-442.

Bena J., Hanousek J. (2006): "Rent Extraction by Large Shareholders: Evidence Using Dividend Policy in the Czech Republic,” CERGE-EI Working Paper No.291.

Claessens S., Djankov S., Klingebiel D. (2000): "Stock Markets in Transition Economies," Financial Sector Discussion Paper No.5, The World Bank.

Czech Republic: Capital Market Review (1999), The World Bank Washington, D.C.

EBRD (European Bank for Reconstruction and Development), 1995 - 2003: Transition Report.

Fine G., Karlova E. (1998): "Privatization and the New Securities Markets in the Czech Republic, Poland and Russia." In Lieberman I., Kirkness Ch.: Privatization and Emerging Equity Markets, co-published by The World Bank and Flemings Washington, D.C.

Filer Randall K., Hanousek J. (2002): "Research Data from Transition Economies," Journal of Economic Perspectives 16(1): 225 - 240.

Fungáčová Z., Hanousek J.: (2006): “A Castle Built on Sand: The Effects of Mass Privatization on Stock Market Creation in Transition Economies," BOFIT Discussion Paper No.14.

Gupta N., Ham J., Švejnar J. (2000): "Priorities and Sequencing in Privatization: Theory and Evidence from the Czech Republic," William Davidson Institute Working Paper No. 323.

Hanousek J. (2000): "Testing of (non-nested) Choice Models via Accuracy of Prediction: A Non-Parametric Approach," Central European Journal of Operations Research 8: 259 - 264. 
Hanousek J., Filer R. (2000): "The Relationship Between Economic Factors and Equity Markets in Central Europe," Economics of Transition 8(3): 623 -638.

Hanousek J., Filer R. (2001): "Informational Content of Prices Set Using Excess Demand: The Natural Experiment of Czech Voucher Privatization," European Economic Review 45: 1619 - 1646.

Hanousek J., Podpiera R. (2004): "Czech Experience with Market Maker Trading System,” Economic Systems 28: 177-191.

Heckman, J. (1979): "Sample Selection Bias as a Specification Error," Econometrica 47, 153-161.

Ježek T. (1997): “Česká republika bude mat' komisiu pre cenné papiere (The Czech Republic will have Security Exchange Commission),”BURZA 12/1997.

Johnson S., La Porta R., Lopez-de-Silanes F., Shleifer A. (2000): “Tunneling,” American Economic Review 90(2): 22 - 27.

King R., Levine R. (1993): "Finance and Growth: Schumpeter Might Be Right," Quarterly Journal of Economics 108(3): 717 - 738.

Korhonen I., Kuus T., Zirnask V. (2000): "Baltic Securities Markets," Bank of Finland Institute for Economies in Transition, Online, No.5.

Kotrba J. (1995): "Privatization Process in the Czech Republic: Players and Winners," pp. 159 - 198, in Švejnar J.: The Czech Republic and Economic Transformation in Eastern Europe, San Diego, London and Toronto: Harcourt Brace, Academic Press.

Köke J., Schröder M. (2002): "The Prospects of Capital Markets in Central and Eastern Europe,” ZEW Discussion Paper No. 02-57.

Levine R., Zervos S. (1998): "Stock Markets, Banks, and Economic Growth," American Economic Review 88: 537 - 558.

Levine R. (2005): "Finance and Growth: Theory and Evidence," in Aghion P., Durlauf S. (eds.), Handbook of Economic Growth, Elsevier North-Holland.

Lieberman I. W. (1997): "Mass Privatization in Comparative Perspective," In Lieberman I., Stilpon N., Raj D. (eds): Between State and Market: Mass Privatization in Transition Economies, The World Bank and OECD.

Macey J., O’Hara M., Pompilio D. (2005): "Down and Out in the Stock Market: The Law and Finance of the Delisting Process," SSRN Electronic Journal, available at http://papers.ssrn.com/sol3/papers.cfm?abstract_id=583401

Mašek F. (2005): "Ani rekordy vše neřeší (Records will not solve all the problems)," Ekonom 3/2005. 
Mašek F. (2005): "Burza vábí další tituly (The Stock Exchange is attracting other share issues)," Ekonom 26/2005.

Megginson W. L. (2005): The Financial Economics of Privatization, New York: Oxford University Press.

Pajuste A. (2002): "Corporate Governance and Stock Market Performance in Central and Eastern Europe: A Study of Nine Countries, 1994 - 2001," SSRN Electronic Journal, available at http://ssrn.com/abstract=310419

Prague Stock Exchange Annual and Monthly Reports (1993 - 2005).

Rozlucki W. (2001): "Emerging Stock Markets in Central Europe: Where Do We Stand?" In Bokros L., Fleming A., Votava C.: Financial Transition in Europe and Central Asia: Challenges of the New Decade, The International Bank for Reconstruction and Development / The World Bank.

Simoneti M. (1997), "Regulating Post-privatization Securities Markets in Transition Economies," In Lieberman I., Stilpon N., Raj D. (eds): Between State and Market: Mass Privatization in Transition Economies, The World Bank and OECD.

The Economist (1991): "Giving companies away is better than keeping them in state hands," September 21, A18-A20.

The Economist (1993): "Making it work," March 13, 90 - 93.

World Development Report 1996: "From Plan to Market," Oxford University Press.

World Bank (2002): "Transition. The First Ten Years: Analysis and Lessons for Eastern Europe and the Former Soviet Union," Washington D. C. 


\section{APPENDIX}

Table A.1: Companies listed and traded on the Warsaw and Budapest Stock Exchange

\begin{tabular}{|c|c|c|c|c|c|c|}
\hline \multirow{2}{*}{} & \multicolumn{2}{|c|}{ WARSAW STOCK EXCHANGE } & \multicolumn{2}{c|}{ BUDAPEST STOCK EXCHANGE } \\
\cline { 2 - 7 } & $\begin{array}{c}\text { New } \\
\text { listings }\end{array}$ & $\begin{array}{c}\text { Listed } \\
\text { companies* }\end{array}$ & $\begin{array}{c}\text { Total turnover } \\
\text { equities } \\
\text { (mil. USD) }\end{array}$ & $\begin{array}{c}\text { New } \\
\text { listings }\end{array}$ & $\begin{array}{c}\text { Number of } \\
\text { equities* }\end{array}$ & $\begin{array}{c}\text { Total turnover - } \\
\text { equities } \\
\text { (mil. USD) }\end{array}$ \\
\hline 1990 & & 28,3 & 6 & 6 & 48,4 \\
1991 & 9 & 9 & 14 & 20 & 65,6 \\
1992 & 7 & 16 & 167,5 & 3 & 23 & 38,0 \\
1993 & 6 & 22 & 4345,7 & 5 & 28 & 99,3 \\
1994 & 22 & 44 & 10305,8 & 12 & 40 & 271,6 \\
1995 & 21 & 65 & 5638,7 & 5 & 42 & 347,1 \\
1996 & 18 & 83 & 11088,2 & 6 & 45 & 1606,7 \\
1997 & 62 & 143 & 15964,4 & 10 & 49 & 7689,7 \\
1998 & 57 & 198 & 17848,6 & 8 & 55 & 16139,6 \\
1999 & 28 & 221 & 22426,0 & 16 & 66 & 14469,3 \\
2000 & 13 & 225 & 38913,6 & 1 & 60 & 12109,5 \\
2001 & 9 & 230 & 19634,7 & 1 & 56 & 4836,7 \\
2002 & 5 & 216 & 15602,8 & 0 & 49 & 5869,7 \\
2003 & 6 & 203 & 20512,3 & 2 & 53 & 8233,1 \\
2004 & 36 & 230 & 32426,3 & 1 & 47 & 12774,6 \\
2005 & 35 & 255 & 59093,0 & 1 & 45 & 24210,5 \\
2006 & 38 & 284 & 107806,0 & 3 & 43 & 30897,4 \\
\hline
\end{tabular}

Note: *depends on the data provided by the stock exchange

Source: Warsaw Stock Exchange

Budapest Stock Exchange

Exchange rates from EIU database

Table A.2: The main stock market indicators from the PSE

\begin{tabular}{|c|c|c|c|c|c|c|c|c|c|c|c|c|c|c|}
\hline & 1993 & 1994 & 1995 & 1996 & 1997 & 1998 & 1999 & 2000 & 2001 & 2002 & 2003 & 2004 & 2005 & 2006 \\
\hline $\begin{array}{l}\text { Total value of trade } \\
\text { (mil. of USD) }\end{array}$ & 309 & 2154 & 7362 & 14485 & 21436 & 26647 & 34351 & 31682 & 52246 & 54770 & 48474 & 45607 & 65717 & 64075 \\
\hline $\begin{array}{l}\text { Value of trade with } \\
\text { shares and units }\end{array}$ & 244 & 1480 & 4732 & 9206 & 7770 & 5347 & 4730 & 6843 & 3386 & 6030 & 9125 & 18666 & 43459 & 37569 \\
\hline $\begin{array}{l}\% \text { of shares and units } \\
\text { in total value of trades }\end{array}$ & 79 & 68,7 & 64,3 & 63,6 & 36,2 & 20,1 & 13,8 & 21,6 & 6,5 & 11 & 18,8 & 40,9 & 66,1 & 58,6 \\
\hline $\begin{array}{l}\text { No. of share and } \\
\text { unit issues }\end{array}$ & 971 & 1028 & 1716 & 1670 & 320 & 304 & 195 & 151 & 102 & 79 & 65 & 55 & 39 & 32 \\
\hline $\begin{array}{l}\text { Market cap. of shares } \\
\text { and units (mil. USD) }\end{array}$ & $x$ & 12267 & 18033 & 19864 & 15638 & 12893 & 13874 & 11475 & 8947 & 14601 & 22847 & 37969 & 55549 & 70456 \\
\hline
\end{tabular}

Source: Prague Stock Exchange 
Figure A.1: Development of the PX-50 stock index on the PSE (1994-2004)

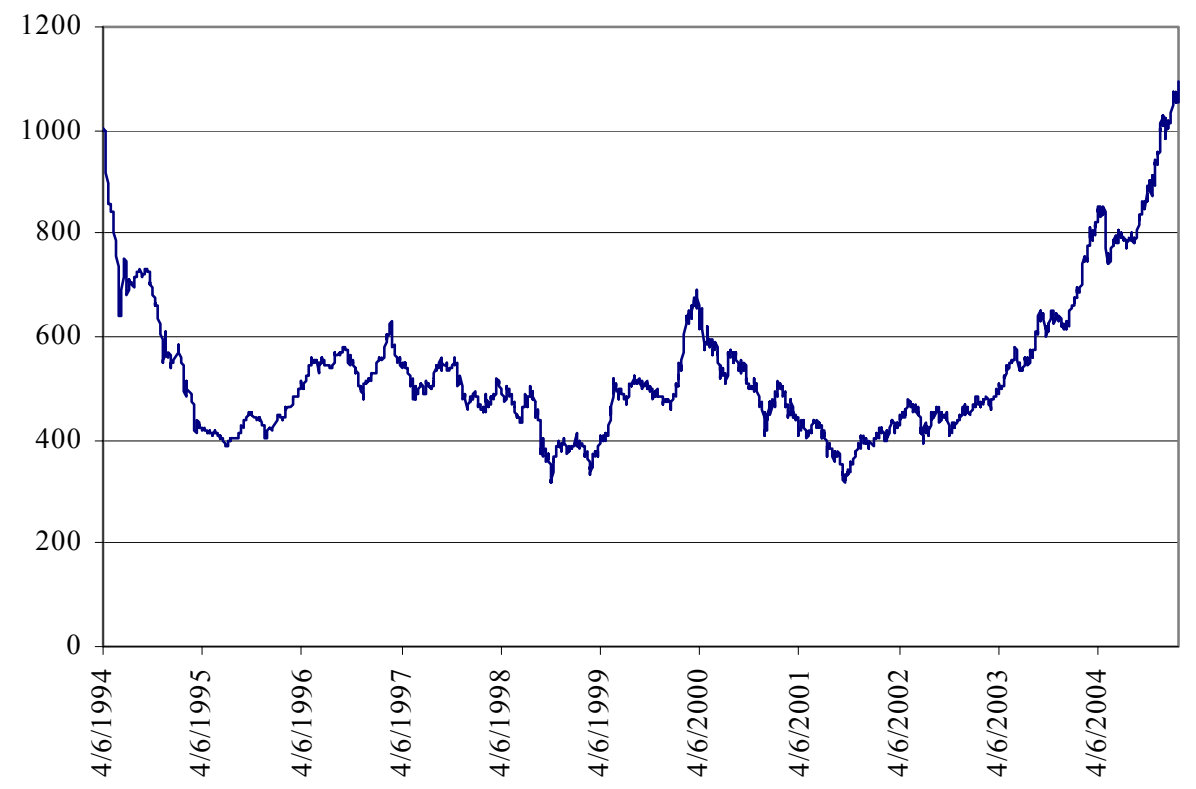

Source: Prague Stock Exchange

Figure A.2: Securities delisted from the PSE (1993 - 2004) - monthly data

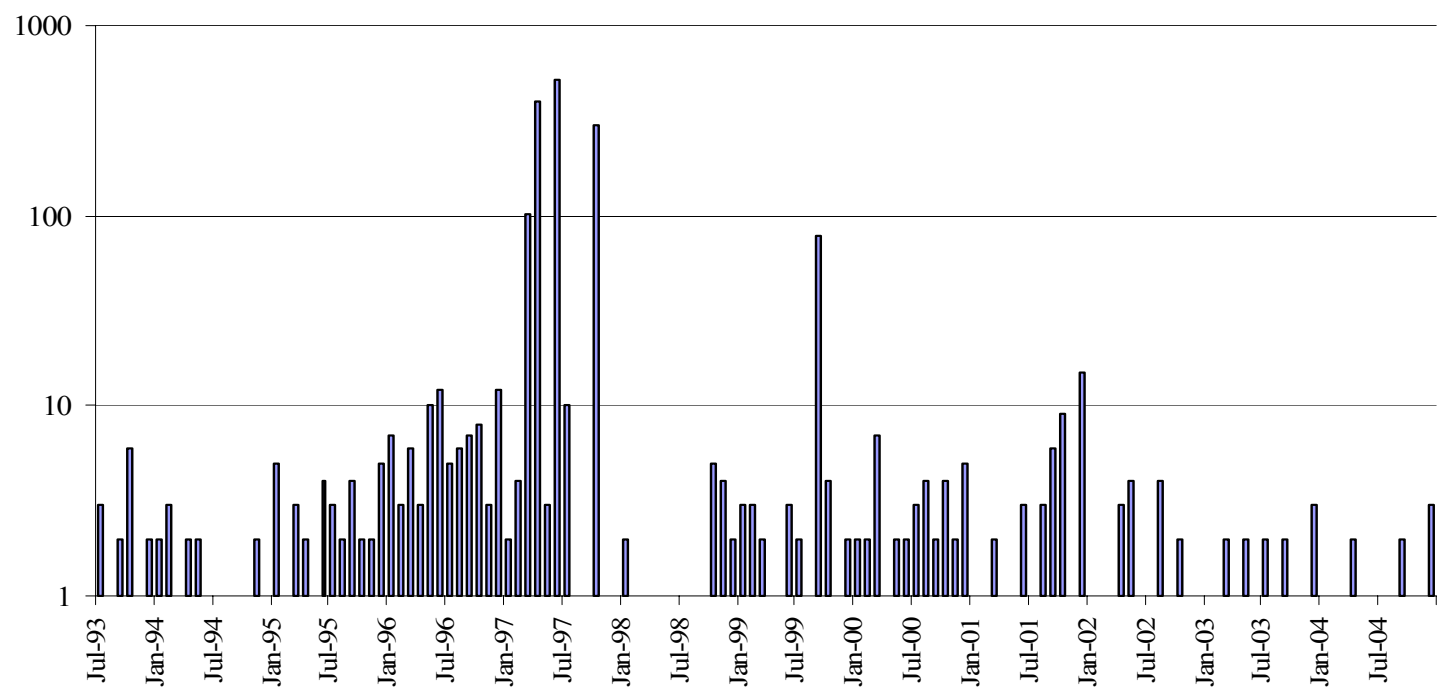

Source: Prague Stock Exchange

Note: The number of delisted shares on the vertical axis is scaled logarithmically. 
Figure A.3: Companies listed on the Prague Stock Exchange by size

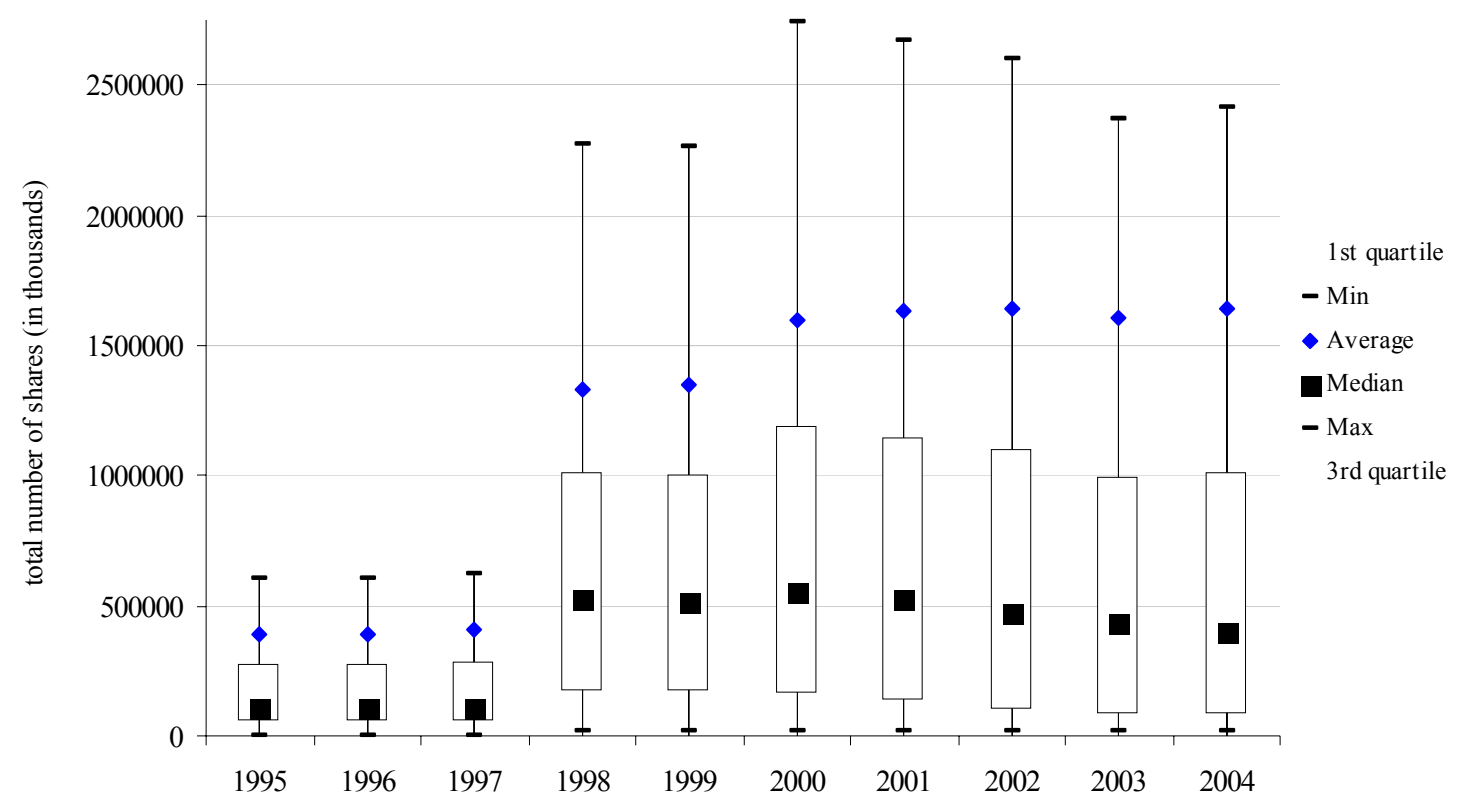

Note: Since the maximum values are extremely high outliers, maximum value is calculated to be the upper quartile plus 1.5 times the value of the interquartile range Source: Prague Stock Exchange

Table A.3: Pre-privatization descriptive statistics of size

\begin{tabular}{|l|c|c|c|c|c|c|c|c|}
\hline \multirow{2}{*}{$\begin{array}{l}\text { PRE- } \\
\text { PRIVATIZATION: }\end{array}$} & \multicolumn{3}{|c|}{$\begin{array}{l}\text { Difference between employees one } \\
\text { and three years before privatization }\end{array}$} & \multicolumn{5}{|c|}{ Total number of shares } \\
\cline { 2 - 9 } & NOB & Mean & Std. Dev. & Median & NOB & Mean & Std. Dev. & Median \\
\hline Delisted & 1,344 & 262 & 1,244 & 87 & 1,510 & 269,000 & 755,000 & 102,000 \\
Not-delisted & 146 & 198 & 526 & 66 & 154 & $1,556,000$ & $5,171,000$ & 347,000 \\
\hline REASONS & & & & & & & & \\
\hline Delisted by issuer & 132 & 440 & 2,657 & 97 & 143 & 788,000 & $1,628,000$ & 241,000 \\
Delisted by authority & 1,166 & 242 & 990 & 86 & 1,314 & 173,000 & 222,000 & 94,000 \\
Bankruptcy related & 46 & 269 & 464 & 126 & 53 & $1,228,000$ & $2,484,000$ & 331,000 \\
\hline TIME & & & & & & & & \\
\hline Delisted before 1997 & 92 & 260 & 420 & 103 & 99 & 124,000 & 176,000 & 64,000 \\
Delisted in 1997 & 1,088 & 246 & 1,021 & 84 & 1,225 & 148,000 & 165,000 & 89,000 \\
Delisted after 1997 & 164 & 369 & 2,387 & 106 & 186 & $1,143,000$ & $1,892,000$ & 609,000 \\
\hline
\end{tabular}


Table A.4: Pre-privatization descriptive statistics - financial variables

\begin{tabular}{|l|c|c|c|c|c|c|c|c|}
\hline \multirow{2}{*}{$\begin{array}{l}\text { PRE-PRIVATIZATION: } \\
\text { VARIABLES }\end{array}$} & \multicolumn{3}{|c|}{$\begin{array}{c}\text { Difference between sales one and three } \\
\text { years before privatization }\end{array}$} & \multicolumn{3}{c|}{ Profit one year before privatization } \\
\cline { 2 - 10 } & NOB & Mean & Std. Dev. & Median & NOB & Mean & Std. Dev. & Median \\
\hline Delisted & 1,321 & $-32,000$ & $1,706,000$ & $-3,939$ & 1,485 & 64,000 & 699,000 & 6,000 \\
Not-delisted & 145 & $-259,000$ & $1,054,000$ & $-18,225$ & 153 & 179,000 & $1,367,000$ & 8,000 \\
\hline REASONS & & & & & & & & \\
\hline Delisted by issuer & 131 & 7,000 & $1,052,000$ & 549 & 139 & 40,000 & 140,000 & 6,000 \\
Delisted by authority & 1,145 & $-35,000$ & $1,795,000$ & $-4,477$ & 1,294 & 66,000 & 746,000 & 6,000 \\
Bankruptcy related & 45 & $-92,000$ & 494,000 & $-3,932$ & 52 & 80,000 & 222,000 & 15,000 \\
\hline TIME & & & & & & & & \\
\hline Delisted before 1997 & 91 & $-4,000$ & 383,000 & -851 & 96 & 58,000 & 182,000 & 4,000 \\
Delisted in 1997 & 1,067 & $-33,000$ & $1,853,000$ & $-3,880$ & 1,205 & 66,000 & 772,000 & 6,000 \\
Delisted after 1997 & 163 & $-46,000$ & $1,015,000$ & $-5,245$ & 184 & 50,000 & 152,000 & 7,000 \\
\hline
\end{tabular}

Table A.5: Descriptive statistics of privatization variables: average price according to privatization waves

\begin{tabular}{|l|c|c|c|c|c|c|c|c|}
\hline \multirow{2}{*}{$\begin{array}{l}\text { PRIVATIZATION } \\
\text { CHARACTERISTICS I }\end{array}$} & \multicolumn{4}{|c|}{$\begin{array}{c}\text { Average price } \\
\text { in the first privatization wave }\end{array}$} & \multicolumn{4}{c|}{$\begin{array}{c}\text { Average price } \\
\text { in the second privatization wave }\end{array}$} \\
\cline { 2 - 10 } & NOB & Mean & Std. Dev. & Median & NOB & Mean & Std. Dev. & Median \\
\hline Delisted & 725 & 43 & 59 & 33 & 627 & 32 & 38 & 21 \\
Not-delisted & 78 & 58 & 60 & 35 & 47 & 77 & 53 & 82 \\
\hline REASONS & & & & & & & & \\
\hline Delisted by issuer & 79 & 48 & 56 & 33 & 36 & 56 & 63 & 28 \\
Delisted by authority & 619 & 43 & 61 & 32 & 580 & 31 & 35 & 21 \\
Bankruptcy related & 27 & 30 & 20 & 24 & 11 & 25 & 13 & 21 \\
\hline TIME & & & & & & & & 29 \\
\hline Delisted before 1997 & 72 & 43 & 56 & 30 & 22 & 25 & 29 & 13 \\
Delisted in 1997 & 589 & 42 & 61 & 32 & 539 & 30 & 35 & 21 \\
Delisted after 1997 & 64 & 48 & 50 & 33 & 66 & 49 & 52 & 29 \\
\hline
\end{tabular}

Table A.6: Descriptive statistics of privatization variables: average price

\begin{tabular}{|l|c|c|c|c|c|c|c|c|}
\hline \multirow{2}{*}{$\begin{array}{l}\text { PRIVATIZATION } \\
\text { CHARACTERISTICS II }\end{array}$} & \multicolumn{3}{|c|}{$\begin{array}{c}\text { Average price for companies } \\
\text { privatized in both waves }\end{array}$} & \multicolumn{3}{c|}{ Average price (the whole sample) } \\
\cline { 2 - 10 } & NOB & Mean & Std. Dev. & Median & NOB & Mean & Std. Dev. & Median \\
\hline Delisted & 158 & 52 & 51 & 37 & 1,510 & 39 & 51 & 27 \\
Not-delisted & 29 & 90 & 113 & 47 & 154 & 70 & 72 & 42 \\
\hline REASONS & & & & & & & & \\
\hline Delisted by issuer & 28 & 104 & 72 & 103 & 143 & 61 & 64 & 36 \\
Delisted by authority & 115 & 41 & 37 & 30 & 1,314 & 37 & 50 & 26 \\
Bankruptcy related & 15 & 43 & 33 & 36 & 53 & 32 & 24 & 27 \\
\hline TIME & & & & & & & & \\
\hline Delisted before 1997 & 5 & 60 & 59 & 47 & 99 & 40 & 52 & 26 \\
Delisted in 1997 & 97 & 42 & 48 & 27 & 1,225 & 37 & 50 & 26 \\
Delisted after 1997 & 56 & 69 & 50 & 50 & 186 & 55 & 51 & 37 \\
\hline
\end{tabular}


Figure A.4: Average price for delisted and non-delisted companies

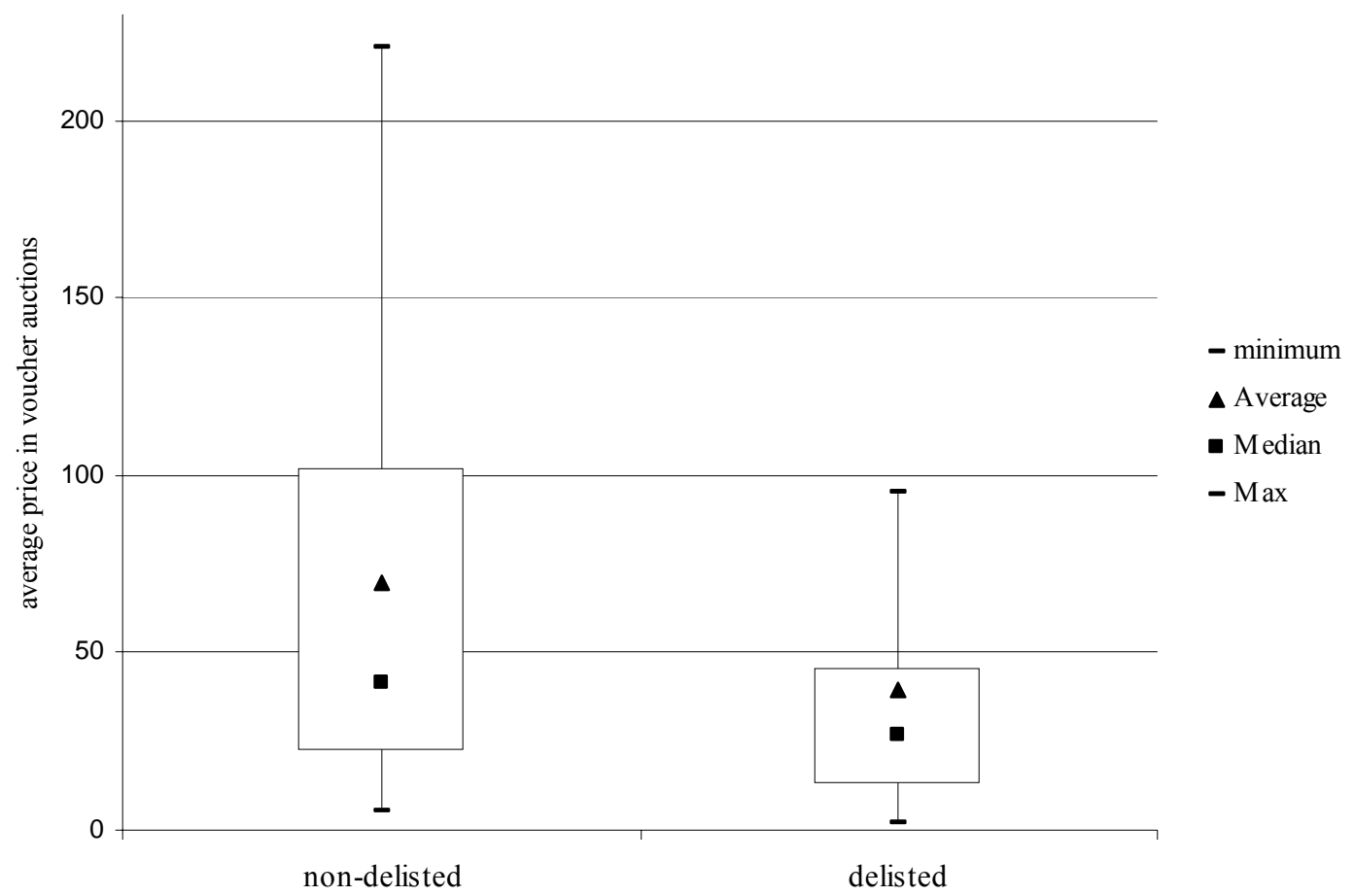

Note: Since the maximum values are extremely high outliers, maximum value is calculated to be the upper quartile plus 1.5 times the value of the interquartile range

Table A.7: Descriptive statistics of privatization variables: investment privatization funds

\begin{tabular}{|l|c|c|c|c|c|c|c|c|}
\hline \multirow{2}{*}{$\begin{array}{l}\text { INVESTMENT } \\
\text { PRIVATIZATION }\end{array}$} & \multicolumn{3}{|c|}{$\begin{array}{l}\text { Investment privatization funds holdings after } \\
\text { FUNDS }\end{array}$} & \multicolumn{3}{|c|}{$\begin{array}{l}\text { Investment privatization funds holdings after } \\
\text { the second wave (\% of total number of shares) }\end{array}$} \\
\cline { 2 - 10 } & NOB & Mean & Std. Dev. & Median & NOB & Mean & Std. Dev. & Median \\
\hline Delisted & 881 & 40 & 21 & 41 & 784 & 24 & 22 & 20 \\
Not-delisted & 107 & 43 & 22 & 45 & 76 & 18 & 19 & 12 \\
\hline REASONS & & & & & & & & \\
\hline Delisted by issuer & 106 & 44 & 22 & 43 & 64 & 20 & 21 & 13 \\
Delisted by authority & 733 & 40 & 21 & 41 & 694 & 25 & 22 & 20 \\
Bankruptcy related & 42 & 37 & 22 & 36 & 26 & 13 & 22 & 4 \\
\hline TIME & & & & & & & & \\
\hline Delisted before 1997 & 77 & 36 & 21 & 37 & 27 & 23 & 23 & 16 \\
Delisted in 1997 & 686 & 40 & 21 & 41 & 635 & 25 & 22 & 20 \\
Delisted after 1997 & 118 & 42 & 21 & 40 & 122 & 18 & 21 & 10 \\
\hline
\end{tabular}


Table A.8: Proportions of missing observations in subgroups of companies delisted due to different reasons

\begin{tabular}{|c|c|c|c|c|c|c|c|c|c|c|}
\hline \multirow[b]{2}{*}{ Variable } & \multirow[b]{2}{*}{ NOB } & \multirow{2}{*}{$\begin{array}{l}\% \text { of } \\
\text { total } \\
\text { NOB }\end{array}$} & \multicolumn{2}{|c|}{ Reason 1:authority } & \multicolumn{2}{|c|}{ Reason2:issuer } & \multicolumn{2}{|c|}{ Reason3:bankruptcy } & \multicolumn{2}{|c|}{ Not delisted } \\
\hline & & & $\begin{array}{c}\text { non- } \\
\text { missing }\end{array}$ & $\begin{array}{l}\% \text { of } \\
\text { total }\end{array}$ & $\begin{array}{c}\text { non- } \\
\text { missing }\end{array}$ & $\begin{array}{l}\% \text { of } \\
\text { total }\end{array}$ & $\begin{array}{c}\text { non- } \\
\text { missing }\end{array}$ & $\begin{array}{l}\% \text { of } \\
\text { total }\end{array}$ & $\begin{array}{c}\text { non- } \\
\text { missing }\end{array}$ & $\begin{array}{l}\% \text { of } \\
\text { total }\end{array}$ \\
\hline Number of shares & 1664 & 100 & 1314 & 100 & 143 & 100 & 53 & 100 & 154 & 100 \\
\hline Profit before priv. & 1656 & 99.52 & 1308 & 99.54 & 142 & 99.30 & 53 & 100 & 153 & 99.35 \\
\hline Sales before priv. & 1648 & 99.04 & 1300 & 98.93 & 141 & 98.60 & 53 & 100 & 154 & 100 \\
\hline Average price & 1664 & 100 & 1314 & 100 & 143 & 100 & 53 & 100 & 154 & 100 \\
\hline Operat. profit 1996 & 1477 & 88.76 & 1209 & 92.01 & 118 & 82.52 & 27 & 50.94 & 123 & 79.87 \\
\hline Sales 1996 & 1465 & 88.04 & 1198 & 91.17 & 117 & 81.82 & 27 & 50.94 & 123 & 79.87 \\
\hline
\end{tabular}

Table A.9: Definitions and data sources of the variables included in the analysis

\begin{tabular}{|c|c|c|}
\hline VARIABLE NAME & SOURCE & DESCRIPTION \\
\hline Industry (ind_id_burza) & PSE classification & $\begin{array}{l}\text { the code of industry at the PSE: it includes } 19 \text { categories } \\
\text { out of which } 17 \text { are relevant for us }\end{array}$ \\
\hline Employees (e3, e2, e1) & $\begin{array}{l}\text { Ministry of Privatization } \\
\text { of the Czech Republic }\end{array}$ & number of employees in the company before privatization \\
\hline Total number of shares (tns) & $\begin{array}{l}\text { Ministry of Privatization of } \\
\text { the Czech Republic (MP CR) }\end{array}$ & $\begin{array}{l}\text { the total number of shares of a firm i.e. capital of a firm } \\
\text { divided by the value of one share }(1000)\end{array}$ \\
\hline Sales $(\mathrm{s} 3, \mathrm{~s} 2, \mathrm{~s} 1)^{*}$ & MP CR & sales prior to privatization (three, two and one year) \\
\hline Profit $(\mathrm{p} 3, \mathrm{p} 2, \mathrm{p} 1)^{*}$ & MP CR & profit prior to privatization (three, two and one year) \\
\hline Debt $(\mathrm{d} 3, \mathrm{~d} 2, \mathrm{~d} 1)^{*}$ & MP CR & debt prior to privatization (three, two and one year) \\
\hline Privatization wave (cvl) & MP CR & $\begin{array}{l}\text { the wave in which certain company was privatized } \\
\text { (first or second); we also distinguish companies that were } \\
\text { privatized in both waves }\end{array}$ \\
\hline $\begin{array}{l}\text { National Property Fund } \\
\text { ownership share (npf) }\end{array}$ & MP CR & $\begin{array}{l}\text { proportion of company's shares that based on the } \\
\text { privatization project were supposed to be owned by the } \\
\text { National Property Fund }\end{array}$ \\
\hline Average price (ap) & MP CR & $\begin{array}{l}\text { average price of the firm's shares sold in the voucher } \\
\text { auctions; sold points divided by shares sold }\end{array}$ \\
\hline $\begin{array}{l}\text { Number of shares in voucher } \\
\text { privatization (nscp_tns) }\end{array}$ & MP CR & $\begin{array}{l}\text { the number of shares offered in the voucher privatization } \\
\text { as } \% \text { of total number of shares }\end{array}$ \\
\hline $\begin{array}{l}\text { IPFs' holdings after } \\
\text { the first wave (ipf1_tns) }\end{array}$ & Prague Securities Centre & $\begin{array}{l}\text { shares held by the investment privatization funds } \\
\text { following the } 1 \text { st privatization wave } \\
\text { (\% of total number of shares) }\end{array}$ \\
\hline $\begin{array}{l}\text { IPFs' holdings after } \\
\text { the second wave (ipf2_tns) }\end{array}$ & Prague Securities Centre & $\begin{array}{l}\text { shares held by the investment privatization funds } \\
\text { following the second privatization wave } \\
\text { (\% of total number of shares) }\end{array}$ \\
\hline Single largest owner (slo) & Prague Securities Centre & $\%$ of shares held by the single largest owner \\
\hline Profit (1996 - 2003) & ASPEKT database & profit defined by Czech accounting standards \\
\hline Operational profit $(1996-2003)$ & ASPEKT database & operational profit defined by Czech accounting standards \\
\hline Sales (1996 - 2003) & ASPEKT database & sales defined by Czech accounting standards \\
\hline Total assets (1996 - 2003) & ASPEKT database & total assets defined by Czech accounting standards \\
\hline Total liabilities (1996 - 2003) & ASPEKT database & total liabilities defined by Czech accounting standards \\
\hline
\end{tabular}

Note: The data marked with * are based on the socialistic accounting 
Table A.10: Results of the McNemar-type test (observed frequencies and $\chi^{2}$ )

\begin{tabular}{|c|c|c|c|c|}
\hline & \multicolumn{3}{|c|}{ OUR MODEL } \\
\hline \multirow{4}{*}{ 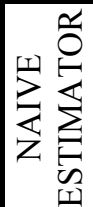 } & outcome & Incorrect & Correct & $\Sigma$ \\
\hline & Incorrect & 10 & 113 & 123 \\
\hline & Correct & 1 & 1346 & 1347 \\
\hline & $\Sigma$ & 11 & 1459 & 1470 \\
\hline
\end{tabular}

Note: Both models predict correctly 1346 delisted companies and 10 that stayed, however our model was in comparison to the naive estimator mistaken only once, while the naive estimator incorrectly predicted 113 cases. This indicates the prediction power of our model that is also confirmed by the test statistic $\chi^{2}=\frac{\left(n_{12}-n_{21}\right)^{2}}{n_{12}+n_{21}}$ that has an asymptotic $\chi^{2}$ distribution. Its value is 110,04 which makes our results significant at all levels. 
Individual researchers, as well as the on-line and printed versions of the CERGE-EI Working Papers (including their dissemination) were supported from the following institutional grants:

- Center of Advanced Political Economy Research [Centrum pro pokročilá politickoekonomická studia], No. LC542, (2005-2009),

- Economic Aspects of EU and EMU Entry [Ekonomické aspekty vstupu do Evropské unie a Evropské měnové unie], No. AVOZ70850503, (2005-2010);

- Economic Impact of European Integration on the Czech Republic [Ekonomické dopady evropské integrace na ČR], No. MSM0021620846, (2005-2011);

Specific research support and/or other grants the researchers/publications benefited from are acknowledged at the beginning of the Paper.

\section{(c) Zuzana Fungáčová, 2007}

All rights reserved. No part of this publication may be reproduced, stored in a retrieval system or transmitted in any form or by any means, electronic, mechanical or photocopying, recording, or otherwise without the prior permission of the publisher.

Published by

Charles University in Prague, Center for Economic Research and Graduate Education (CERGE) and

Economics Institute ASCR, v. v. i. (EI)

CERGE-El, Politických vězňů 7, 11121 Prague 1, tel.: +420 224005 153, Czech Republic.

Printed by CERGE-EI, Prague

Subscription: CERGE-EI homepage: http://www.cerge-ei.cz

Editors: Directors of CERGE and EI

Managing editors: Deputy Directors for Research of CERGE and EI

ISSN 1211-3298

ISBN 978-80-7343-134-1 (Univerzita Karlova. Centrum pro ekonomický výzkum

a doktorské studium)

ISBN 978-80-7344-123-4 (Národohospodářský ústav AV ČR, v. v. i.) 
CERGE-EI

P.O.BOX 882

Politických vězňủ 7

11121 Praha 1

Czech Republic

http://www.cerge-ei.cz 